Supporting Information

\title{
Discovery of a Potent and Selective Covalent Inhibitor of Bruton's Tyrosine Kinase with Oral Anti-Inflammatory Activity
}

Author list

Mark S. Tichenor ${ }^{+*}$, John J.M. Wiener ${ }^{\dagger}$, Navin L. Rao ${ }^{*^{*}}$, Charlotte Pooley Deckhut ${ }^{\dagger}$, J. Kent

Barbay $^{\ddagger}$, Kevin D. Kreutter ${ }^{\ddagger}$, Genesis M. Bacani ${ }^{\dagger}$, Jianmei Wei $^{\dagger}$, Leon Chang ${ }^{\dagger}$, Heather E.

Murrey $\ddagger$, Weixue Wang ${ }^{\ddagger}$, Kay Ahn ${ }^{\ddagger}$, Michael Huber ${ }^{\dagger}$, Elizabeth Rex ${ }^{\dagger}$, Kevin J. Coe ${ }^{\dagger}, J_{i e J u n ~} \mathrm{Wu}^{\dagger}$,

Mark Seierstad ${ }^{\dagger}$, Scott D. Bembenek ${ }^{\dagger}$, Kristi A. Leonard ${ }^{\ddagger}$, Alec D. Lebsack $^{\dagger}$, Jennifer D.

Venable $^{\dagger}$, James P. Edwards ${ }^{\dagger}$

$\dagger$ †anssen Research \& Development, 3210 Merryfield Row, San Diego, USA 92121-1126

¥Janssen Research \& Development, 1400 McKean Road, Spring House, PA, USA 19477-0776

* Correspondence may be addressed to: Mark Tichenor (mticheno@its.jnj.com) and Navin Rao (nrao2@its.jnj.com)

\section{Contents of Supporting Information:}

Figure S1. Determination of the atropisomer interconversion barrier for compound $21 \quad$ S2

Figure S2. Determination of the atropisomer interconversion barrier for compound $23 \quad$ S3

$\begin{array}{ll}\text { Figure S3. Characterization of BTK covalent adduct } & \text { S4 }\end{array}$

Figure S4. Kinase selectivity profile of compound $\mathbf{2 7}$ in a human wild type kinase panel S5 (Eurofins).

Synthesis methods for compounds 9-30 

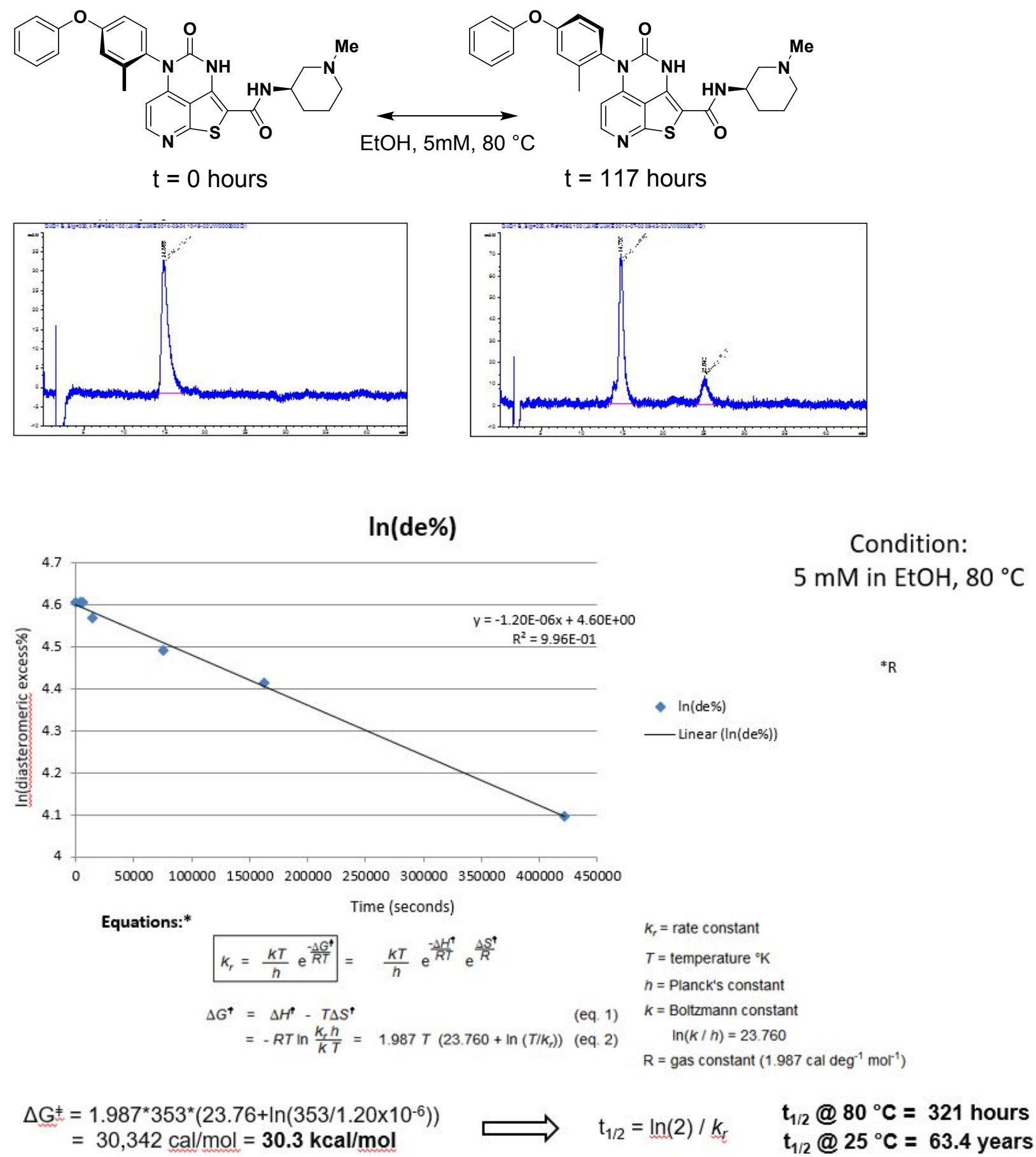

Figure S1. Determination of the atropisomer interconversion barrier for 21 . 

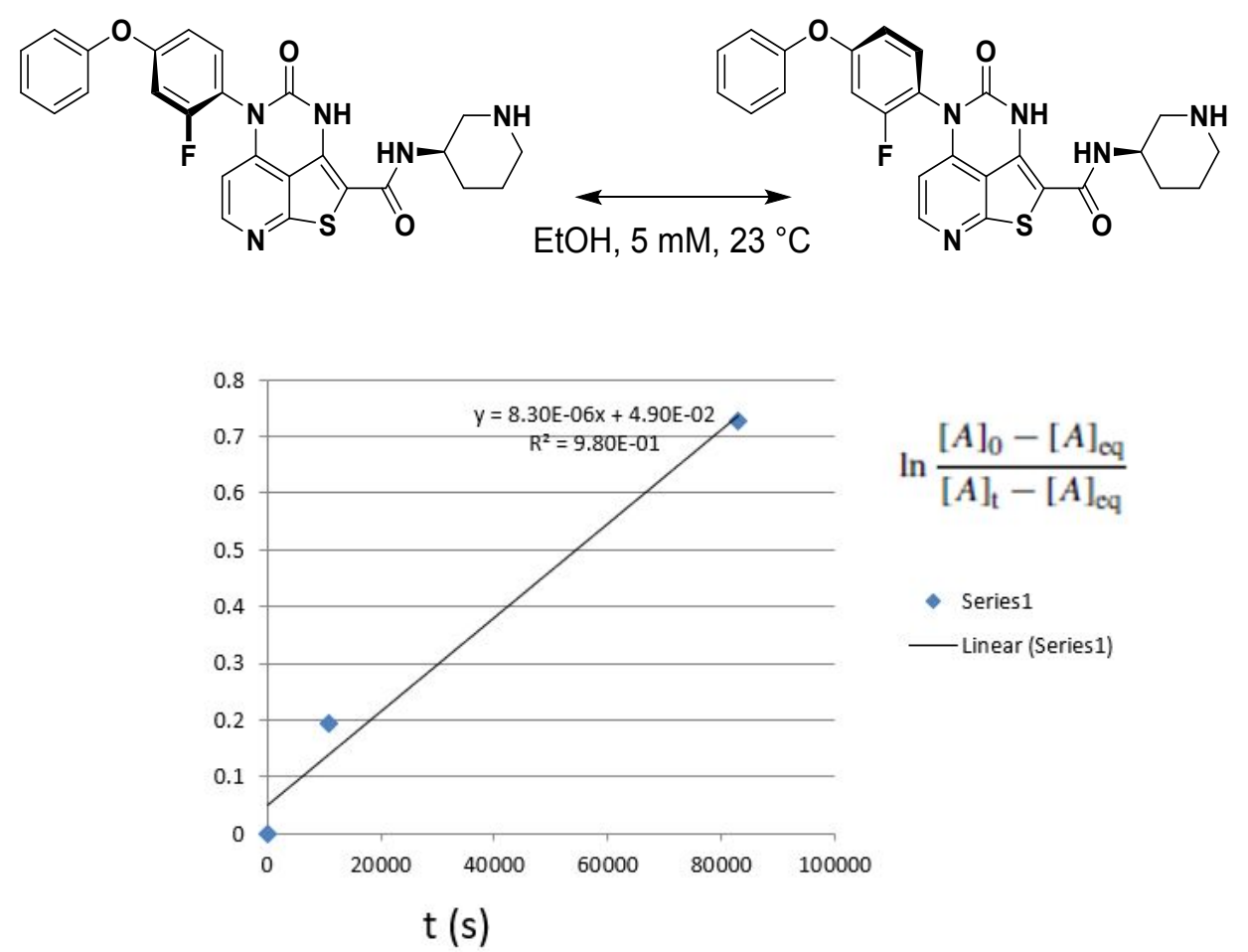

From regression plot: $\mathrm{k}=$ slope $/ 2=4.15^{*} 10^{-6} \mathrm{~s}^{-1}$

$$
\begin{aligned}
\Delta G^{\#}=R T \ln \left(\frac{h k}{\kappa k_{\mathrm{B}} T}\right) & =8.314 \mathrm{~J} \mathrm{~K}^{-1} \mathrm{~mol}^{-1} * 296 \mathrm{~K} * \frac{\ln \frac{\left(6.626 * 10^{-34} \mathrm{~J} \mathrm{~s}^{*} 4.15^{*} 10^{-6} \mathrm{~s}^{-1}\right)}{\left(0.5 * 1.38 * 10^{-23} \mathrm{~J} \mathrm{~K}^{-1 * 296 \mathrm{~K})}\right.}}{} \\
& =101.3 \mathrm{~kJ} / \mathrm{mol}=24.2 \mathrm{kcal} / \mathrm{mol} \mathrm{t}_{1 / 2} \text { at } 23^{\circ} \mathrm{C}=\frac{\ln 2}{\mathrm{k}}=46 \mathrm{hr}
\end{aligned}
$$

Figure S2. Determination of the atropisomer interconversion barrier for 23. 


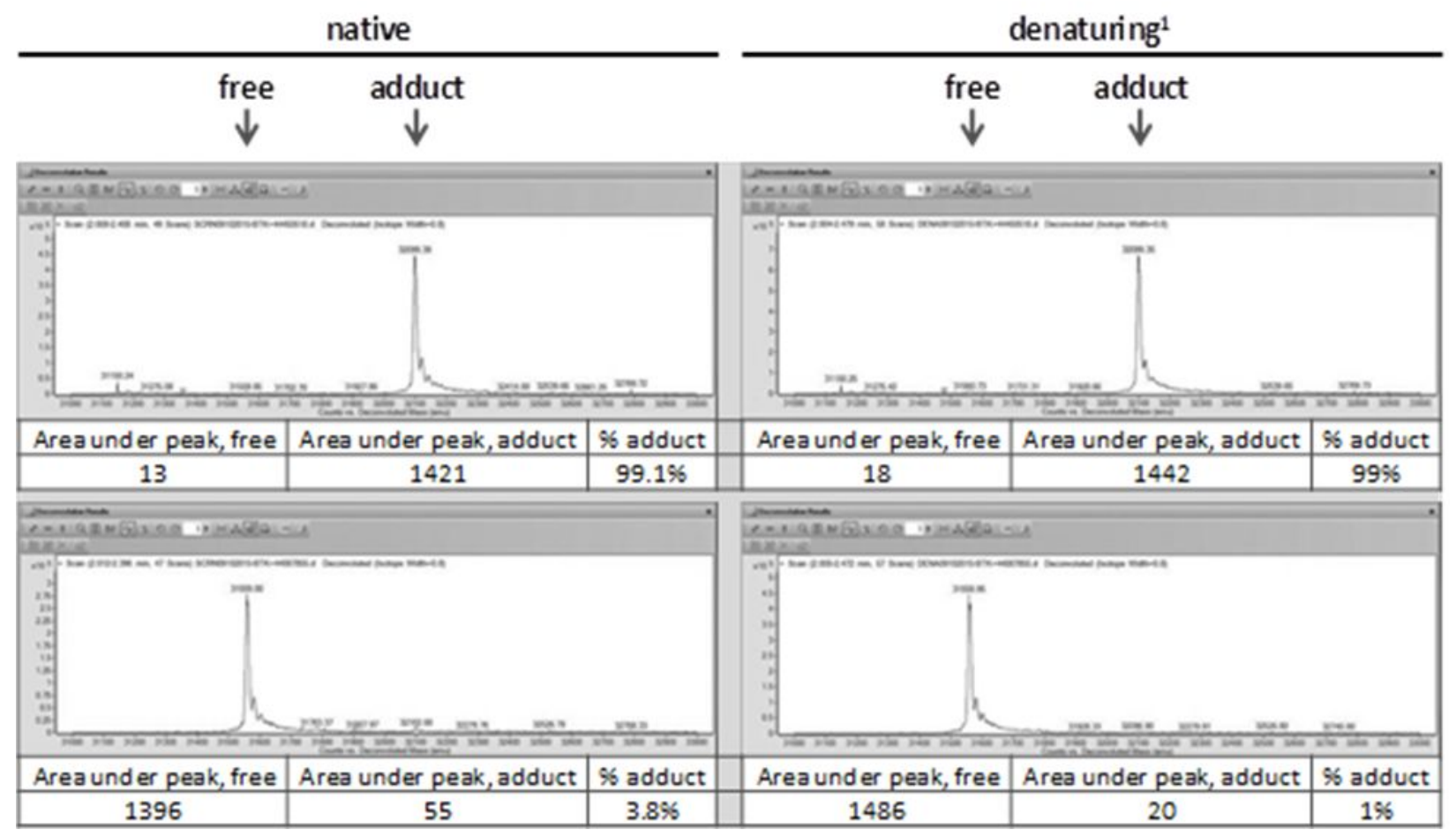

Figure S3. Characterization of BTK inhibitor adduct.

Covalent modification of BTK by compound 27. To verify the covalent mechanism, compound 27 was incubated with BTK protein followed by purification using a C18 reverse phase column under non-denaturing and denaturing conditions $\left(8 \mathrm{M}\right.$ urea, $\left.70{ }^{\circ} \mathrm{C}\right)$. The expected mass of free (unmodified) recombinant BTK kinase domain used in this assay is 31,560 Da, and the expected mass of BTK adduct with compound 27 is 32,100 Da. A compound that causes a shift of $>95 \%$ of BTK to the expected higher molecular weight under native LC/MS conditions and maintains a similar degree $( \pm 2-3 \%)$ of BTK modification under denaturing conditions is classified as an irreversible covalent inhibitor. The measured mass of the adduct was 32,099.36 Da with abundancies of $>98 \%$ under both denaturing and non-denaturing conditions, confirming 27 as an irreversible covalent inhibitor of BTK. 
Figure S4. Kinase selectivity profile of compound 27 in a human wild type kinase panel at $1 \mu \mathrm{M}$ (Eurofins).

\begin{tabular}{|c|c|}
\hline Assay & $\begin{array}{l}\text { Compound } \mathbf{2 7} \% \\
\text { effect at } 1 \mu \mathrm{M}\end{array}$ \\
\hline Bruton agammaglobulinemia tyrosine kinase_h_wt_AS_10uMATP & 101 \\
\hline BMX non-receptor tyrosine kinase _h_wt_AS_10uMATP & 99 \\
\hline tec protein tyrosine kinase (activated)_h_wt_AS_10uMATP & 92 \\
\hline lymphocyte-specific protein tyrosine kinase_h_wt_AS_10uMATP & 89 \\
\hline $\begin{array}{l}\text { v-erb-a erythroblastic leukemia viral oncogene homolog } \\
\text { 4_h_wt_AS_10uMATP }\end{array}$ & 86 \\
\hline TXK tyrosine kinase_h_wt_AS_10uMATP & 79 \\
\hline $\begin{array}{l}\text { lymphocyte-specific protein tyrosine kinase } \\
\text { (activated)_h_wt_AS_10uMATP }\end{array}$ & 75 \\
\hline $\begin{array}{l}\text { Gardner-Rasheed feline sarcoma viral (v-fgr) oncogene } \\
\text { homolog_h_wt_AS_10uMATP }\end{array}$ & 63 \\
\hline $\begin{array}{l}\text { v-raf-1 murine leukemia viral oncogene homolog } \\
\text { 1_h_wt_AS_10uMATP }\end{array}$ & 62 \\
\hline hemopoietic cell kinase_h_wt_AS_10uMATP & 57 \\
\hline c-src tyrosine kinase_h_wt_AS_10uMATP & 57 \\
\hline fms-related tyrosine kinase 4_h_wt_AS_10uMATP & 48 \\
\hline PTK6 protein tyrosine kinase 6_h_wt_AS_10uMATP & 47 \\
\hline epidermal growth factor receptor_h_wt_AS_10uMATP & 37 \\
\hline fyn-related kinase_h_wt_AS_10uMATP & 37 \\
\hline $\begin{array}{l}\text { v-abl Abelson murine leukemia viral oncogene homolog } 2 \\
\text { _h_wt_AS_10uMATP }\end{array}$ & 36 \\
\hline FYN oncogene related to SRC, FGR, YES_h_wt_AS_10uMATP & 35 \\
\hline $\begin{array}{l}\text { v-yes-1 Yamaguchi sarcoma viral related oncogene homolog } \\
\text { h_wt_AS_10uMATP }\end{array}$ & 35 \\
\hline B lymphoid tyrosine kinase_h_wt_AS_10uMATP & 32 \\
\hline serine/threonine kinase 17a_h_wt_AS_10uMATP & 28 \\
\hline 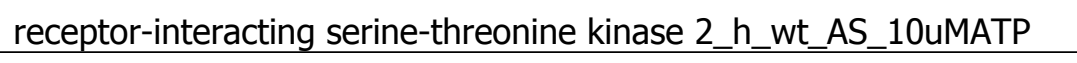 & 27 \\
\hline EPH receptor B2_h_wt_AS_10uMATP & 24 \\
\hline PAS domain containing serine/threonine kinase _h_wt_AS_10uMATP & 22 \\
\hline v-src sarcoma viral oncogene homolog_h_wt_AS_10uMATP & 20 \\
\hline spleen tyrosine kinase_h_wt_AS_10uMATP & 19 \\
\hline Cyclin-dependent kinase 7 / cyclinH / MAT_h_wt_AS_10uMATP & 18 \\
\hline interleukin-1 receptor-associated kinase $1 \_\mathrm{h} \_w t \_A S \_10$ & 18 \\
\hline
\end{tabular}




\begin{tabular}{|c|c|}
\hline $\begin{array}{l}\text { ribosomal protein S6 kinase, 90kDa, polypeptide } 2 \\
\text { _h_wt_AS_10uMATP }\end{array}$ & 17 \\
\hline serine/threonine kinase 33_h_wt_AS_10uMATP & 17 \\
\hline kinase insert domain receptor_h_wt_AS_10uMATP & 16 \\
\hline dystrophia myotonica-protein kinase_h_wt_AS_10uMATP & 16 \\
\hline EPH receptor A2_h_wt_AS_10uMATP & 15 \\
\hline tyrosine kinase, non-receptor, 2 _h_wt_AS_10uMATP & 13 \\
\hline hemopoietic cell kinase (activated)_h_wt_AS_10uMATP & 13 \\
\hline aurora kinase C_h_wt_AS_10uMATP & 13 \\
\hline SFRS protein kinase 3_h_wt_AS_10uMATP & 12 \\
\hline TEK tyrosine kinase, endothelial_h_wt_AS_10uMATP & 12 \\
\hline phosphorylase kinase, gamma 2_h_wt_AS_10uMATP & 12 \\
\hline serum/glucocorticoid regulated kinase 1_h_wt_AS_10uMATP & 12 \\
\hline interleukin-1 receptor-associated kinase 4_h_wt_AS_10uMATP & 12 \\
\hline 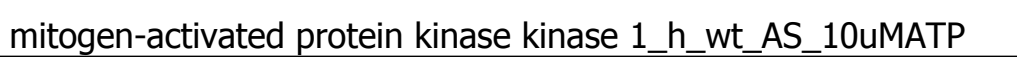 & 12 \\
\hline $\begin{array}{l}\text { phosphoinositide-3-kinase, catalytic, gamma } \\
\text { polypeptide_h_wt_AS_10uMATP }\end{array}$ & 12 \\
\hline Janus kinase 3_h_wt_AS_10uMATP & 11.5 \\
\hline 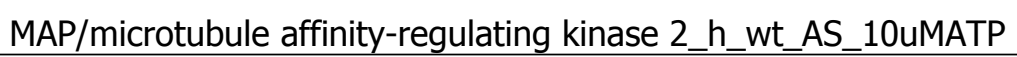 & 11 \\
\hline p21 protein -activated kinase 2_h_wt_AS_10uMATP & 11 \\
\hline Janus kinase 3_h_wt_AS_10uMATP & 10.5 \\
\hline EPH receptor A3_h_wt_AS_10uMATP & 10 \\
\hline NIMA -related kinase 2_h_wt_AS_10uMATP & 10 \\
\hline germ cell associated 2 (haspin)_h_wt_AS_10uMATP & 10 \\
\hline protein kinase $\mathrm{C}$, gamma_h_wt_AS_10uMATP & 10 \\
\hline glycogen synthase kinase 3 beta_h_wt_AS_10uMATP & 10 \\
\hline casein kinase 1 , gamma 2 _h_wt_AS_10uMATP & 10 \\
\hline LIM domain kinase 1_h_wt_AS_10uMATP & 10 \\
\hline EPH receptor A8_h_wt_AS_10uMATP & 10 \\
\hline $\begin{array}{l}\text { ribosomal protein S6 kinase, 70kDa, polypeptide } 1 \\
\text { h_wt_AS_10uMATP }\end{array}$ & 10 \\
\hline SNF1-like kinase_h_wt_AS_10uMATP & 10 \\
\hline $\begin{array}{l}\text { v-akt murine thymoma viral oncogene homolog } 2 \\
\text { h_wt_AS_10uMATP }\end{array}$ & 9 \\
\hline muscle, skeletal, receptor tyrosine kinase _h_wt_AS_10uMATP & 9 \\
\hline serine/threonine kinase 24 h_wt_AS_10uMATP & 9 \\
\hline $\begin{array}{l}\text { ribosomal protein S6 kinase, 90kDa, polypeptide } \\
\text { 4_h_wt_AS_10uMATP }\end{array}$ & 9 \\
\hline
\end{tabular}




\begin{tabular}{|c|c|}
\hline casein kinase 1, gamma 3_h_wt_AS_10uMATP & 9 \\
\hline pim-3 oncogene_h_wt_AS_10uMATP & 9 \\
\hline protein kinase $\mathrm{C}$, beta 1 h_wwt_AS_10uMATP & 9 \\
\hline Janus kinase 3_h_wt_AS_10uMATP & 8 \\
\hline EPH receptor B4_h_wt_AS_10uMATP & 8 \\
\hline serine/threonine kinase 10_h_wt_AS_10uMATP & 8 \\
\hline $\begin{array}{l}\text { calcium/calmodulin-dependent protein kinase II delta } \\
\text { h_wt_AS_10uMATP }\end{array}$ & 8 \\
\hline $\begin{array}{l}\text { protein kinase, AMP-activated, alpha } 1 \text { catalytic } \\
\text { subunit_h_wt_AS_10uMATP }\end{array}$ & 8 \\
\hline fms-related tyrosine kinase 1_h_wt_AS_10uMATP & 7 \\
\hline myosin light chain kinase_h_wt_AS_10uMATP & 7 \\
\hline p21 protein -activated kinase 5_h_wt_AS_10uMATP & 7 \\
\hline 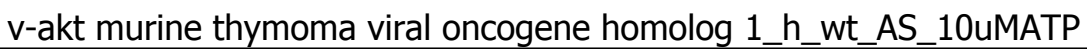 & 7 \\
\hline $\begin{array}{l}\text { mitogen-activated protein kinase-activated protein kinase } \\
\text { 5_h_wt_AS_10uMATP }\end{array}$ & 7 \\
\hline mitogen-activated protein kinase kinase 6_h_wt_AS_10uMATP & 7 \\
\hline BR serine/threonine kinase 1 _h_wt_AS_10uMATP & 6 \\
\hline nemo-like kinase_h_wt_AS_10uMATP & 6 \\
\hline eukaryotic elongation factor-2 kinase_h_wt_AS_10uMATP & 6 \\
\hline mitogen-activated protein kinase 11 h $\mathrm{h}$ wt_AS_10uMATP & 6 \\
\hline TYRO3 protein tyrosine kinase_h_wt_AS_10uMATP & 6 \\
\hline protein kinase $\mathrm{C}$, epsilon_h_wt_AS_10uMATP & 6 \\
\hline mitogen-activated protein kinase 1 _h_wt_AS_10uMATP & 6 \\
\hline NIMA -related kinase 11_h_wt_AS_10uMATP & 6 \\
\hline macrophage stimulating 1 receptor_h_wt_AS_10uMATP & 6 \\
\hline CDC-like kinase 2_h_wt_AS_10uMATP & 6 \\
\hline Janus kinase 3_h_wt_AS_10uMATP & 5 \\
\hline $\begin{array}{l}\text { inhib of kappa light polypeptide gene enhancer in B-cells, kinase beta } \\
\text { _h_wt_AS_10uMATP }\end{array}$ & 5 \\
\hline EPH receptor A5_h_wt_AS_10uMATP & 5 \\
\hline $\begin{array}{l}\text { v-yes-1 Yamaguchi sarcoma viral oncogene homolog } 1 \\
\text { h_wt_AS_10uMATP }\end{array}$ & 5 \\
\hline CHK2 checkpoint homolog (S. pombe)_h_wt_AS_10uMATP & 5 \\
\hline casein kinase 1, gamma 1_h_wt_AS_10uMATP & 5 \\
\hline casein kinase 1 , delta _h_wt_AS_10uMATP & 5 \\
\hline $\begin{array}{l}\text { platelet-derived growth factor receptor, alpha polypeptide } \\
\text { h_wt_AS_10uMATP }\end{array}$ & 5 \\
\hline
\end{tabular}




\begin{tabular}{|c|c|}
\hline $\begin{array}{l}\text { v-kit Hardy-Zuckerman } 4 \text { feline sarcoma viral oncogene } \\
\text { homolog_h_wt_AS_10uMATP }\end{array}$ & 5 \\
\hline TAO kinase 1_h_wt_AS_10uMATP & 5 \\
\hline fms-related tyrosine kinase 3_h_wt_AS_10uMATP & 4 \\
\hline neurotrophic tyrosine kinase, receptor, type 1_h_wt_AS_10uMATP & 4 \\
\hline testis-specific serine kinase 1B_h_wt_AS_10uMATP & 4 \\
\hline $\begin{array}{l}\text { phosphoinositide-3-kinase, catalytic, delta } \\
\text { polypeptide_h_wt_AS_10uMATP }\end{array}$ & 4 \\
\hline $\begin{array}{l}\text { calcium/calmodulin-dependent protein kinase II beta } \\
\text { h_wt_AS_10uMATP }\end{array}$ & 4 \\
\hline CDC42 binding protein kinase alpha (DMPK-like) _h_wt_AS_10uMATP & 4 \\
\hline EPH receptor A1_h_wt_AS_10uMATP & 3 \\
\hline CHK1 checkpoint homolog (S. pombe)_h_wt_AS_10uMATP & 3 \\
\hline $\begin{array}{l}\text { v-akt murine thymoma viral oncogene homolog } 3 \\
\text { _h_wt_AS_10uMATP }\end{array}$ & 3 \\
\hline protein kinase D1_h_wt_AS_10uMATP & 3 \\
\hline protein kinase $\mathrm{C}$, zeta_h_wt_AS_10uMATP & 3 \\
\hline death-associated protein kinase 2_h_wt_AS_10uMATP & 3 \\
\hline c-abl oncogene 1, receptor tyrosine kinase_h_wt_AS_10uMATP & 3 \\
\hline maternal embryonic leucine zipper kinase_h_wt_AS_10uMATP & 3 \\
\hline aurora kinase $B \_h \_w t \_A S \_10 u M A T P$ & 3 \\
\hline Janus kinase 3_h_wt_AS_10uMATP & 2.5 \\
\hline $\begin{array}{l}\text { ribosomal protein S6 kinase, } 90 \mathrm{kDa} \text {, polypeptide } 5 \\
\text { h_wt_AS_10uMATP }\end{array}$ & 2 \\
\hline unc-51-like kinase 3_h_wt_AS_10uMATP & 2 \\
\hline pim-2 oncogene_h_wt_AS_10uMATP & 2 \\
\hline protein kinase $\mathrm{C}$, alpha_h_wt_AS_10uMATP & 2 \\
\hline $\begin{array}{l}\text { serum/glucocorticoid regulated kinase family, member } \\
\text { 3_h_wt_AS_10uMATP }\end{array}$ & 2 \\
\hline $\begin{array}{l}\text { ribosomal protein S6 kinase, } 90 \mathrm{kDa} \text {, polypeptide } 3 \\
\text { h_wt_AS_10uMATP }\end{array}$ & 2 \\
\hline Janus kinase 3_h_wt_AS_10uMATP & 1.5 \\
\hline Janus kinase 3_h_wt_AS_10uMATP & 1.5 \\
\hline Janus kinase 3_h_wt_AS_10uMATP & 1 \\
\hline $\begin{array}{l}\text { phosphoinositide-3-kinase, catalytic, beta polypeptide } \\
\text { _h_wt_AS_10uMATP }\end{array}$ & 1 \\
\hline $\begin{array}{l}\text { mitogen-activated protein kinase-activated protein kinase } \\
\text { 3_h_wt_AS_10uMATP }\end{array}$ & 1 \\
\hline homeodomain interacting protein kinase $2 \_\mathrm{h} \_\mathrm{mt} \_$AS_10uMATP & 1 \\
\hline EPH receptor A7_h_wt_AS_10uMATP & 1 \\
\hline serum/glucocorticoid regulated kinase 2_h_wt_AS_10uMATP & 1 \\
\hline
\end{tabular}




\begin{tabular}{|c|c|}
\hline TAO kinase 2_h_mt_AS_10uMATP & 1 \\
\hline $\begin{array}{l}\text { mitogen-activated protein kinase kinase kinase kinase } 2 \\
\text { _h_wt_AS_10uMATP }\end{array}$ & 1 \\
\hline casein kinase 2 , alpha 1 polypeptide_h_wt_AS_10uMATP & 1 \\
\hline serine/threonine kinase 3 _h_wt_AS_10uMATP & 1 \\
\hline death-associated protein kinase $1 \_h \_w t \_A S \_10 u M A T P$ & 1 \\
\hline $\begin{array}{l}\text { phosphatidylinositol-4-phosphate 5-kinase, type I, } \\
\text { alpha_h_wt_AS_10uMATP }\end{array}$ & 1 \\
\hline $\begin{array}{l}\text { phosphoinositide-3-kinase catalytic alpha polypeptide } \\
\text { p85_h_wt_AS_10uMATP }\end{array}$ & 1 \\
\hline MAP kinase interacting serine/threonine kinase 2 h & 0 \\
\hline serine/threonine kinase 4_h_wt_AS_10uMATP & 0 \\
\hline cyclin-dependent kinase 1 / clyclinB_h_wt_AS_10uMATP & 0 \\
\hline SFRS protein kinase 1_h_wt_AS_10uMATP & 0 \\
\hline tousled-like kinase 2_h_wt_AS_10uMATP & 0 \\
\hline PTK2B protein tyrosine kinase 2 beta_h_wt_AS_10uMATP & 0 \\
\hline aurora kinase A_h_wt_AS_10uMATP & 0 \\
\hline polo-like kinase 1_h_wt_AS_10uMATP & 0 \\
\hline unc-51-like kinase 2_h_wt_AS_10uMATP & 0 \\
\hline $\begin{array}{l}\text { phosphatidylinositol-5-phosphate 4-kinase, type II, alpha } \\
\text { h_wt_AS_10uMATP }\end{array}$ & 0 \\
\hline Janus kinase 3_h_wt_AS_10uMATP & -0.5 \\
\hline protein kinase $\mathrm{C}$, beta 2 _h_wt_AS_10uMATP & -1 \\
\hline protein kinase, cGMP-dependent, type II_h_wt_AS_10uMATP & -1 \\
\hline calcium/calmodulin-dependent protein kinase I_h_wt_AS_10uMATP & -1 \\
\hline serine/threonine kinase 11_h_wt_AS_10uMATP & -1 \\
\hline feline sarcoma oncogene_h_wt_AS_10uMATP & -1 \\
\hline casein kinase 2, alpha prime polypeptide_h_wt_AS_10uMATP & -1 \\
\hline fibroblast growth factor receptor 4_h_wt_AS_10uMATP & -1 \\
\hline pim-1 oncogene_h_wt_AS_10uMATP & -1 \\
\hline insulin-like growth factor 1 receptor_h_wt_AS_10uMATP & -1 \\
\hline $\begin{array}{l}\text { platelet-derived growth factor receptor, beta polypeptide } \\
\text { h_wt_AS_10uMATP }\end{array}$ & -1 \\
\hline doublecortin-like kinase 2_h_wt_AS_10uMATP & -1 \\
\hline conserved helix-loop-helix ubiquitous kinase_h_wt_AS_10uMATP & -1 \\
\hline NIMA -related kinase 3_h_wt_AS_10uMATP & -1 \\
\hline mechanistic target of rapamycin / FKBP12_h_wt_AS_10uMATP & -1 \\
\hline insulin receptor-related receptor_h_wt_AS_10uMATP & -2 \\
\hline
\end{tabular}




\begin{tabular}{|c|c|}
\hline AXL receptor tyrosine kinase_h_wt_AS_10uMATP & -2 \\
\hline G protein-coupled receptor kinase 6_h_wt_AS_10uMATP & -2 \\
\hline polo-like kinase 3_h_wt_AS_10uMATP & -2 \\
\hline G protein-coupled receptor kinase 5_h_wt_AS_10uMATP & -2 \\
\hline $\begin{array}{l}\text { dual-specificity tyrosine-(Y)-phosphorylation regulated kinase } 2 \\
\text { h_wt_AS_10uMATP }\end{array}$ & -2 \\
\hline polo-like kinase 2_h_wt_AS_10uMATP & -2 \\
\hline mitogen-activated protein kinase 12 h_h_wt_AS_10uMATP & -2 \\
\hline $\begin{array}{l}\text { phosphatidylinositol-4-phosphate 5-kinase, type I, } \\
\text { gamma_h_wt_AS_10uMATP }\end{array}$ & -2 \\
\hline zeta-chain associated protein kinase 70kDa_h_wt_AS_10uMATP & -3 \\
\hline cyclin-dependent kinase 3 / cyclinE_h_wt_AS_10uMATP & -3 \\
\hline calcium/calmodulin-dependent protein kinase ID_h_wt_AS_10uMATP & -3 \\
\hline 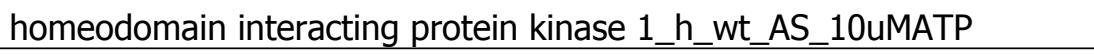 & -3 \\
\hline NUAK family, SNF1-like kinase, 1 h_wt_AS_10uMATP & -3 \\
\hline p21 protein -activated kinase 4_h_wt_AS_10uMATP & -3 \\
\hline mitogen-activated protein kinase 14_h_wt_AS_10uMATP & -3 \\
\hline discoidin domain receptor tyrosine kinase 2_h_wt_AS_10uMATP & -3 \\
\hline protein kinase, $\mathrm{X}$-linked_h_wt_AS_10uMATP & -3 \\
\hline G protein-coupled receptor kinase 7_h_wt_AS_10uMATP & -3 \\
\hline $\begin{array}{l}\text { ribosomal protein S6 kinase, 90kDa, polypeptide } 1 \\
\text { h_wt_AS_10uMATP }\end{array}$ & -4 \\
\hline fer (fps/fes related) tyrosine kinase_h_wt_AS_10uMATP & -4 \\
\hline activin A receptor, type 1B_h_wt_AS_10uMATP & -4 \\
\hline 3-phosphoinositide dependent protein kinase-1_h_wt_AS_10uMATP & -4 \\
\hline MAP/microtubule affinity-regulating kinase 1_h_wt_AS_10uMATP & -4 \\
\hline colony stimulating factor 1 receptor_h_wt_AS_10uMATP & -4 \\
\hline glycogen synthase kinase 3 alpha_h_wt_AS_10uMATP & -4 \\
\hline mitogen-activated protein kinase 8 _h_wt_AS_10uMATP & -4 \\
\hline cyclin-dependent kinase 2 / clyclinA_h_wt_AS_10uMATP & -4 \\
\hline mechanistic target of rapamycin_h_wt_AS_10uMATP & -4 \\
\hline cyclin-dependent kinase 6 / cyclinD3_h_wt_AS_10uMATP & -5 \\
\hline mitogen-activated protein kinase kinase kinase 9_h_wt_AS_10uMATP & -5 \\
\hline SFRS protein kinase 2_h_wt_AS_10uMATP & -5 \\
\hline testis-specific serine kinase 2 _h_wt_AS_10uMATP & -5 \\
\hline CDC-like kinase 3_h_wt_AS_10uMATP & -6 \\
\hline fibroblast growth factor receptor 2_h_wt_AS_10uMATP & -6 \\
\hline
\end{tabular}




\begin{tabular}{|c|c|}
\hline NIMA -related kinase 6_h_wt_AS_10uMATP & -6 \\
\hline c-ros oncogene 1 , receptor tyrosine kinase $\mathrm{h}$ _wt_AS_10uMATP & -6 \\
\hline $\begin{array}{l}\text { Rho-associated, coiled-coil containing protein kinase } \\
\text { 1_h_wt_AS_10uMATP }\end{array}$ & -6 \\
\hline $\begin{array}{l}\text { mitogen-activated protein kinase-activated protein kinase } \\
\text { 2_h_wt_AS_10uMATP }\end{array}$ & -6 \\
\hline vaccinia related kinase 2 _h_wt_AS_10uMATP & -6 \\
\hline cyclin-dependent kinase 9 / cyclinT1_h_wt_AS_10uMATP & -6 \\
\hline $\begin{array}{l}\text { calcium/calmodulin-dependent protein kinase II } \\
\text { gamma_h_wt_AS_10uMATP }\end{array}$ & -6 \\
\hline $\begin{array}{l}\text { phosphoinositide-3-kinase, class 2, alpha polypeptide } \\
\text { h_wt_AS_10uMATP }\end{array}$ & -6 \\
\hline protein kinase D2_h_wt_AS_10uMATP & -7 \\
\hline insulin receptor_h_wt_AS_10uMATP & -7 \\
\hline fibroblast growth factor receptor 3_h_wt_AS_10uMATP & -7 \\
\hline $\begin{array}{l}\text { phosphoinositide-3-kinase, class 2, gamma polypeptide } \\
\text { h_wt_AS_10uMATP }\end{array}$ & -7 \\
\hline cyclin-dependent kinase 2 /clyclinE_h_wt_AS_10uMATP & -8 \\
\hline mitogen-activated protein kinase 9_h_wt_AS_10uMATP & -8 \\
\hline mitogen-activated protein kinase kinase kinase $5 \_h \_w t \_A S \_10 u M A T P$ & -8 \\
\hline TANK-binding kinase 1_h_wt_AS_10uMATP & -8 \\
\hline $\begin{array}{l}\text { Rho-associated, coiled-coil containing protein kinase } \\
\text { 2_h_wt_AS_10uMATP }\end{array}$ & -8 \\
\hline homeodomain interacting protein kinase 3_h_wt_AS_10uMATP & -8 \\
\hline NIMA -related kinase 7_h_wt_AS_10uMATP & -8 \\
\hline c-mer proto-oncogene tyrosine kinase_h_wt_AS_10uMATP & -8 \\
\hline IL2-inducible T-cell kinase_h_wt_AS_10uMATP & -8 \\
\hline protein kinase $\mathrm{C}$, delta_h_wt_AS_10uMATP & -8 \\
\hline $\begin{array}{l}\text { protein kinase, AMP-activated, alpha } 2 \text { catalytic } \\
\text { subunit_h_wt_AS_10uMATP }\end{array}$ & -8 \\
\hline mitogen-activated protein kinase kinase 7_h_wt_AS_10uMATP & -9 \\
\hline p21 protein -activated kinase 6_h_wt_AS_10uMATP & -9 \\
\hline BR serine/threonine kinase 2_h_wt_AS_10uMATP & -9 \\
\hline protein kinase N2_h_wt_AS_10uMATP & -9 \\
\hline CDC42 binding protein kinase beta (DMPK-like)_h_wt_AS_10uMATP & -9 \\
\hline $\begin{array}{l}\text { ribosomal protein S6 kinase, 90kDa, polypeptide } 6 \\
\text { _h_wt_AS_10uMATP }\end{array}$ & -10 \\
\hline mitogen-activated protein kinase 10_h_wt_AS_10uMATP & -10 \\
\hline protein kinase $\mathrm{C}$, iota_h_wt_AS_10uMATP & -10 \\
\hline misshapen-like kinase 1 h_wt_AS_10uMATP & -10 \\
\hline
\end{tabular}




\begin{tabular}{|l|r|}
\hline mitogen-activated protein kinase 13_h_wt_AS_10uMATP & -11 \\
\hline insulin receptor (activated)_h_wt_AS_10uMATP & -11 \\
\hline TAO kinase 3_h_wt_AS_10uMATP & -12 \\
\hline EPH receptor A4_h_wt_AS_10uMATP & -12 \\
\hline cyclin-dependent kinase 5 / p25_h_wt_AS_10uMATP & -12 \\
\hline EPH receptor B3_h_wt_AS_10uMATP & -12 \\
\hline EPH receptor B1 _h_wt_AS_10uMATP & -13 \\
\hline death-associated protein kinase 3_h_wt_AS_10uMATP & -13 \\
\hline cyclin-dependent kinase 5 / p35_h_wt_AS_10uMATP & -13 \\
\hline protein kinase, cGMP-dependent, type I_h_wt_AS_10uMATP & -14 \\
\hline PTK2 protein tyrosine kinase 2_h_wt_AS_10uMATP & -14 \\
\hline mitogen-activated protein kinase 1 (MAPK2)_h_wt_AS_10uMATP & -14 \\
\hline WNK lysine deficient protein kinase 2_h_wt_AS_10uMATP & -14 \\
\hline calcium/calmodulin-dependent protein kinase IV_h_wt_AS_10uMATP & -14 \\
\hline insulin-like growth factor 1 receptor (activated)_h_wt_AS_10uMATP & -14 \\
\hline fibroblast growth factor receptor 1_h_wt_AS_10uMATP & -15 \\
\hline protein kinase C, theta_h_wt_AS_10uMATP & -15 \\
\hline WNK lysine deficient protein kinase 3_h_wt_AS_10uMATP & -17 \\
\hline ret proto-oncogene h_wt_AS_10uMATP & -18 \\
\hline protein kinase, cAMP-dependent, catalytic, alpha_h_wt_AS_10uMATP & -19 \\
\hline mitogen-activated protein kinase kinase kinase 7 & -19 \\
\hline h_wt_AS_10uMATP & -22 \\
\hline transf proto-oncogene_h_wt_AS_10uMATP & -23 \\
\hline protein kinase C, eta_h_wt_AS_10uMATP & -24 \\
\hline neurotrophic tyrosine kinase, receptor, type 2_h_wt_AS_10uMATP & -25 \\
\hline Janus kinase 2_h_wt_AS_10uMATP & -25 \\
\hline anaplastic lymphoma receptor tyrosine kinase_h_wt_AS_10uMATP & -31 \\
\hline
\end{tabular}




\section{Representative synthesis methods for compounds 9-30}

Experimental Details. No unexpected or unusually high safety hazards were encountered. All solvents and chemicals were used as purchased without further purification. Nuclear magnetic resonance (NMR) spectra were obtained on Bruker model DRX spectrometers. Chemical shifts $(\delta)$ are expressed in parts per million, relative to internal tetramethylsilane; coupling constants (J) are in hertz $(\mathrm{Hz})$. The following abbreviations are used to describe peak patterns when appropriate: $\mathrm{s}$ (singlet), d (doublet), t (triplet), q (quartet), qt (quintet), m (multiplet), app (apparent), and br (broad). HPLC-MS chromatograms and spectra were obtained using one of the following methods, and purity of all final compounds was confirmed to be $>95 \%$ : (1) Agilent 1200 HPLC and G6100 system on X-Bridge ShieldRP18 $(50 \times 2.1 \mathrm{~mm}, 5 \mu \mathrm{m})$ and a gradient system of $0.05 \%$ $\mathrm{NH}_{4} \mathrm{OH}$ in $\mathrm{H}_{2} \mathrm{O} / \mathrm{CH}_{3} \mathrm{CN}, 100: 0$ to 5:95 over $7.5 \mathrm{~min}$, then 100:0 for $2.5 \mathrm{~min}$ at a temperature of 40 ${ }^{\circ} \mathrm{C}$; (2) Agilent 1200 HPLC and G6100 system on Phenomenex Luna-C18 (50 $\left.\times 2 \mathrm{~mm}, 5 \mu \mathrm{m}\right)$ and a gradient system of $0.1 \%$ TFA in $\mathrm{H}_{2} \mathrm{O} / 0.05 \%$ TFA in $\mathrm{CH}_{3} \mathrm{CN}, 100: 0$ to 15:85 over 7.5 min, then 100:0 for $2.5 \mathrm{~min}$ at a temperature of $50^{\circ} \mathrm{C}$; or (3) Agilent 1100 HPLC and G1367A system on XBridge $\mathrm{C} 18(100 \times 3 \mathrm{~mm}, 3.5 \mathrm{uM})$ and a gradient system of $20 \mathrm{mM} \mathrm{NH} \mathrm{OH}_{4} \mathrm{On} \mathrm{H}_{2} \mathrm{O} / \mathrm{CH}_{3} \mathrm{CN} 90: 10$ over $2 \mathrm{~min}$, then $0: 100$ for $1 \mathrm{~min}$ at a flow rate of $2.4 \mathrm{~mL} / \mathrm{min}$ at a temperature of $45^{\circ} \mathrm{C}$. All compounds tested were of a minimum of $95 \%$ purity as determined by HPLC.<smiles>CC(C)(C)OC(=O)N1CCC[C@H](NC(=O)CS)C1</smiles>

tert-Butyl (3R)-3-[(2-sulfanylacetyl)amino]piperidine-1-carboxylate. To a 10-20 $\mathrm{mL}$ microwave vial was added (R)-1-boc-3-aminopiperidine (5.02 g, $25.0 \mathrm{mmol})$. The vial was sealed and evacuated and back-filled with argon three times and then methyl 2-mercaptoacetate $(6.7 \mathrm{~mL}, 75$ mmol) was added via syringe in one portion and the vial was heated in a $150{ }^{\circ} \mathrm{C}$ oil bath. After 1 
h 35 minutes, the mixture was cooled to room temperature and was purified by $\mathrm{FCC}\left(\mathrm{SiO}_{2}\right.$, EtOAc/hexanes) to give the title compound $(5.54 \mathrm{~g}, 80.6 \%)$. The purified product contained the disulfide (di-tert-butyl 3,3'-((2,2'-disulfanediylbis(acetyl))bis(azanediyl))(3R,3'R)-bis(piperidine1-carboxylate)) as a biproduct, but was used as is in the next reaction. MS (ESI): mass calcd. for $\mathrm{C}_{8} \mathrm{H}_{15} \mathrm{~N}_{2} \mathrm{O}_{3} \mathrm{~S}, 219.08[\mathrm{M}-\mathrm{tBu}+\mathrm{H}]^{+} ; \mathrm{m} / \mathrm{z}$ found, 219.1. ${ }^{1} \mathrm{H} \mathrm{NMR}\left(400 \mathrm{MHz}, \mathrm{CDCl}_{3}\right.$ ): $\delta$ 6.73-7.00 (br $\mathrm{m}, 1 \mathrm{H}), 3.96$ (br s, 1H), 3.14-3.66 (m, 6H), 1.53-1.91 (m, 5H), 1.47 (s, 9H).

\section{General method 1: Compound 10.}<smiles>CC(C)Oc1ccc(Nc2ccnc(Cl)c2C#N)cc1</smiles>

2-Chloro-4-(4-isopropoxyanilino)pyridine-3-carbonitrile. To a $20 \mathrm{~mL}$ microwave vial was added sequentially 2-chloro-4-iodonicotinonitrile (300 mg, $1.13 \mathrm{mmol})$, 4-isopropoxyaniline (172 mg, $1.13 \mathrm{mmol})$, palladium(II) acetate $(5.0 \mathrm{mg}, 0.023 \mathrm{mmol})$, bis(2-diphenylphosphinophenyl)ether (18 mg, $0.034 \mathrm{mmol})$, and $\mathrm{Cs}_{2} \mathrm{CO}_{3}(517 \mathrm{mg}, 1.59 \mathrm{mmol})$ and the vial was sealed and evacuated and refilled with argon three times. To this vial was added 1,4-dioxane $(2.2 \mathrm{~mL})$ and the vial was evacuated and refilled with argon once. The reaction mixture was heated for 5 minutes in a $50{ }^{\circ} \mathrm{C}$ oil bath under an argon inlet needle, then the inlet needle was removed, and the sealed vial was heated for 30 minutes in a $150{ }^{\circ} \mathrm{C}$ oil bath. The crude reaction mixture was used directly in the next step. MS (ESI): mass calcd. for $\mathrm{C}_{15} \mathrm{H}_{15} \mathrm{ClN}_{3} \mathrm{O}[\mathrm{M}+\mathrm{H}]^{+} 288.01 ; \mathrm{m} / \mathrm{z}$ found, 288.3. 


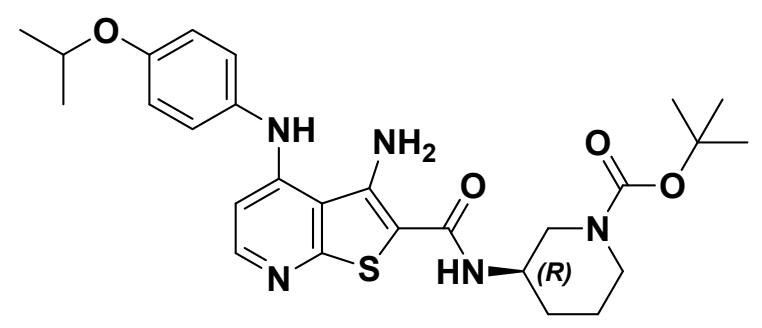

$\underline{(R) \text {-tert-Butyl }}$

3-(3-amino-4-((4-isopropoxyphenyl)amino)thieno[2,3-b]pyridine-2-

carboxamido)piperidine-1-carboxylate. To the sealed tube containing 2-chloro-4-(4isopropoxyanilino)pyridine-3-carbonitrile $(326 \mathrm{mg}, 1.13 \mathrm{mmol})$ was added a solution of tert-butyl (3R)-3-[(2-sulfanylacetyl)amino]piperidine-1-carboxylate in dioxane (0.5 M, $2.7 \mathrm{~mL}, 1.4 \mathrm{mmol})$. The resulting brown suspension was heated in the sealed tube in a $150{ }^{\circ} \mathrm{C}$ oil bath for 15 minutes. The mixture was cooled to room temperature to give the title compound as a crude mixture, which was used in the next reaction without purification. $M S$ (ESI): mass calcd. for $\mathrm{C}_{27} \mathrm{H}_{36} \mathrm{~N}_{5} \mathrm{O}_{4} \mathrm{~S}, 526.25$ $[\mathrm{M}+\mathrm{H}]^{+} ; \mathrm{m} / \mathrm{z}$ found, 526.5 .

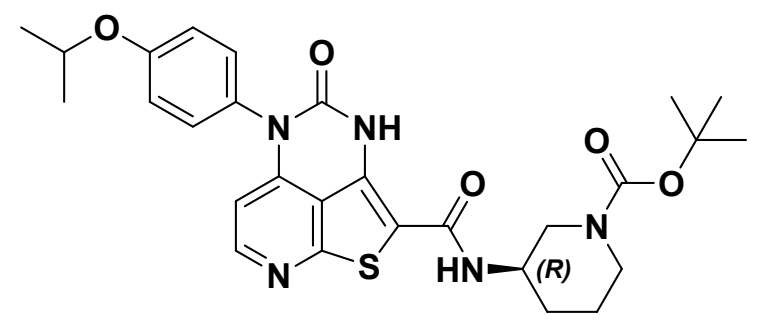

(R)-tert-Butyl

3-(5-(4-isopropoxyphenyl)-4-oxo-4,5-dihydro-3H-1-thia-3,5,8triazaacenaphthylene-2-carboxamido)piperidine-1-carboxylate. To the crude mixture of $(R)$-tertbutyl 3-(3-amino-4-((4-isopropoxyphenyl)amino)thieno[2,3- $b]$ pyridine-2carboxamido)piperidine-1-carboxylate was added 1,1' '-carbonyldiimidazole (0.736 g, $4.54 \mathrm{mmol})$. The tube was sealed, and the vessel was evacuated and refilled with argon twice. The mixture was heated for 5 minutes in a $50{ }^{\circ} \mathrm{C}$ oil bath under an argon inlet needle, then the argon inlet needle was removed, and the mixture was heated at $150{ }^{\circ} \mathrm{C}$ for 10 minutes. The mixture was cooled to room temperature and was partitioned between EtOAc $(50 \mathrm{~mL})$ and $\mathrm{H}_{2} \mathrm{O}(50 \mathrm{~mL})$. The aqueous phase was extracted with EtOAc $(2 \times 50 \mathrm{~mL})$ and the combined organic extracts were washed with saturated aqueous $\mathrm{NaCl}(50 \mathrm{~mL})$, followed by $1 \mathrm{~N}$ aqueous $\mathrm{HCl}(50 \mathrm{~mL})$. The organic phase was dried over anhydrous $\mathrm{Na}_{2} \mathrm{SO}_{4}$, filtered, and concentrated to dryness. The residue was purified FCC $\left(\mathrm{SiO}_{2}, \mathrm{EtOAc} / \mathrm{hexanes}\right)$ to give the title compound as a tan foamy solid (449 mg, 72\%). MS (ESI): 
mass calcd. for $\mathrm{C}_{28} \mathrm{H}_{34} \mathrm{~N}_{5} \mathrm{O}_{5} \mathrm{~S}, 552.23 ; \mathrm{m} / \mathrm{z}$ found, $552.5[\mathrm{M}+\mathrm{H}]^{+} .{ }^{1} \mathrm{H}$ NMR (400 MHz, $\left.\mathrm{CDCl}_{3}\right): \delta$ 9.47 (s, 1H), 8.34 (d, $J=5.56 \mathrm{~Hz}, 1 \mathrm{H}), 7.19-7.25$ (m, 2H), 7.04 (d, $J=9.09 \mathrm{~Hz}, 2 \mathrm{H}), 6.13$ (d, $J=5.56$ $\mathrm{Hz}, 1 \mathrm{H}), 4.60$ (spt, $J=6.06 \mathrm{~Hz}, 1 \mathrm{H}), 4.08-4.16(\mathrm{~m}, 1 \mathrm{H}), 3.23-3.68(\mathrm{~m}, 4 \mathrm{H}), 1.66-1.96(\mathrm{~m}, 3 \mathrm{H}), 1.50$ (s, 9H), 1.43-1.47 (m, 1H), 1.39 (d, $J=6.06 \mathrm{~Hz}, 6 \mathrm{H})$.

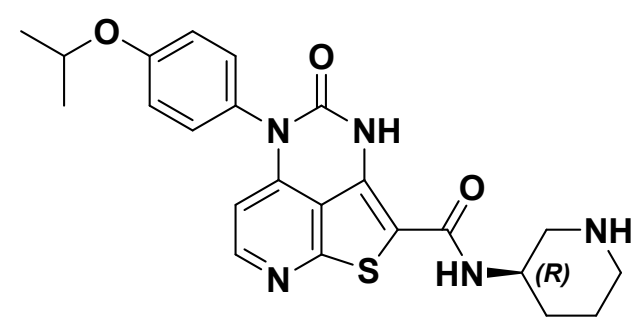

Compound 9: (R)-5-(4-Isopropoxyphenyl)-4-oxo- $N$-(piperidin-3-yl)-4,5-dihydro-3H-1-thia-3,5,8triazaacenaphthylene-2-carboxamide hydrochloride. To a solution of $(R)$-tert-butyl 3-(5-(4isopropoxyphenyl)-4-oxo-4,5-dihydro-3H-1-thia-3,5,8-triazaacenaphthylene-2-

carboxamido)piperidine-1-carboxylate $(421.8 \mathrm{mg}, 0.765 \mathrm{mmol})$ in dioxane $(4 \mathrm{~mL})$ was added $\mathrm{HCl}$ in dioxane $(4.0 \mathrm{~mL}, 4.0 \mathrm{M}, 16 \mathrm{mmol})$ and the mixture was stirred at room temperature under air for 20 minutes. The reaction mixture was concentrated to dryness and the residue was dried under vacuum to give the crude title compound as a tan powder (459.2 mg, crude). MS (ESI): mass calcd. for $\mathrm{C}_{23} \mathrm{H}_{26} \mathrm{~N}_{5} \mathrm{O}_{3} \mathrm{~S}, 452.18[\mathrm{M}+\mathrm{H}]^{+} ; \mathrm{m} / \mathrm{z}$ found, $452.1 .{ }^{1} \mathrm{H}$ NMR (400 MHz, DMSO- $\left.d_{6}\right): \delta 10.17(\mathrm{~s}$, 1H), 8.62-8.80 (m, 2H), $8.38(\mathrm{~d}, J=5.56 \mathrm{~Hz}, 1 \mathrm{H}), 8.21(\mathrm{~d}, J=7.07 \mathrm{~Hz}, 1 \mathrm{H}), 7.38(\mathrm{~d}, J=7.58 \mathrm{~Hz}$, 2H), 7.15 (d, $J=9.09 \mathrm{~Hz}, 2 \mathrm{H}), 6.09$ (d, $J=5.56 \mathrm{~Hz}, 1 \mathrm{H}), 4.74$ (spt, $J=5.89 \mathrm{~Hz}, 1 \mathrm{H}), 4.14-4.26$ (m, $1 \mathrm{H}), 3.24-3.43(\mathrm{~m}, 2 \mathrm{H}), 2.80-2.95(\mathrm{~m}, 2 \mathrm{H}), 1.88-2.02(\mathrm{~m}, 2 \mathrm{H}), 1.60-1.82(\mathrm{~m}, 2 \mathrm{H}), 1.37(\mathrm{~d}$, $6 \mathrm{H})$.

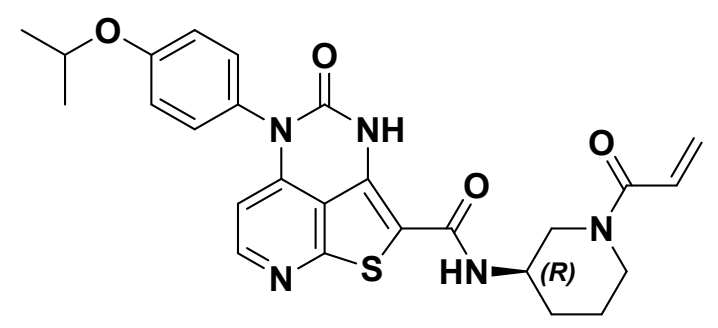

Compound 10: (R)- $N$-(1-Acryloylpiperidin-3-yl)-5-(4-isopropoxyphenyl)-4-oxo-4,5-dihydro-3H1-thia-3,5,8-triazaacenaphthylene-2-carboxamide. To a solution of $(R)$-5-(4-isopropoxyphenyl)-4oxo- $N$-(piperidin-3-yl)-4,5-dihydro-3H-1-thia-3,5,8-triazaacenaphthylene-2-carboxamide $\cdot \mathrm{HCl}$ (93.2 mg, $0.191 \mathrm{mmol})$ in DCM $(1 \mathrm{~mL})$ was added TEA $(79 \mu \mathrm{L}, 0.57 \mathrm{mmol})$ followed by acryloyl 
chloride ( $15 \mu \mathrm{L}, 0.19 \mathrm{mmol})$ dropwise via syringe. The resulting suspension was stirred under air at $0{ }^{\circ} \mathrm{C}$ for $40 \mathrm{~min}$. The reaction mixture was partitioned between DCM $(10 \mathrm{~mL})$ and saturated aqueous $\mathrm{NaHCO}_{3}(10 \mathrm{~mL})$. The aqueous phase was extracted once with EtOAc $(10 \mathrm{~mL})$ and the combined organic extracts were dried over anhydrous $\mathrm{Na}_{2} \mathrm{SO}_{4}$, filtered, and concentrated to dryness. The residue was purified by $\mathrm{FCC}\left(\mathrm{SiO}_{2}\right.$, EtOAc/hexanes) to give the title compound as a yellow powder (32.2 mg, 33\%). MS (ESI): mass calcd. for $\mathrm{C}_{26} \mathrm{H}_{28} \mathrm{~N}_{5} \mathrm{O}_{4} \mathrm{~S}, 506.19[\mathrm{M}+\mathrm{H}]^{+} ; \mathrm{m} / \mathrm{z}$ found, 506.2. ${ }^{1} \mathrm{H}$ NMR (400 MHz, $\mathrm{CDCl}_{3}$ ): $\delta 9.46$ (s, $1 \mathrm{H}$ ), 8.34 (br s., $1 \mathrm{H}$ ), $7.22(\mathrm{~d}, J=7.58 \mathrm{~Hz}$, 2H), 7.04 (d, $J=8.59 \mathrm{~Hz}, 2 \mathrm{H}), 6.63$ (dd, $J=10.86,16.93 \mathrm{~Hz}, 1 \mathrm{H}), 6.28-6.49$ (m, 1H), 6.24 (br. s., 0.5H), 6.06-6.19 (m, 1H), 5.68-5.82 (m, 1H), 5.49 (br. s., $0.5 \mathrm{H}), 4.60$ (spt, $J=5.98 \mathrm{~Hz}, 1 \mathrm{H}$ ), 3.84$4.24(\mathrm{~m}, 2.5 \mathrm{H}), 3.28-3.77(\mathrm{~m}, 2.5 \mathrm{H}), 1.68-2.14(\mathrm{~m}, 4 \mathrm{H}), 1.39$ (d, $J=6.06 \mathrm{~Hz}, 6 \mathrm{H})$.

\section{General Method 2: Compound 16}<smiles>Cc1cc(Oc2ccccc2)ccc1[N+](=O)[O-]</smiles>

Compound 32: 2-Methyl-1-nitro-4-phenoxybenzene. To a round bottom flask were added phenol (42.5 g, $452 \mathrm{mmol}), \mathrm{K}_{2} \mathrm{CO}_{3}(125 \mathrm{~g}, 905 \mathrm{mmol})$, and DMF (500 mL). To the reaction mixture was added 5-fluoro-2-nitrotoluene $(70.2 \mathrm{~g}, 452 \mathrm{mmol})$ and the reaction was stirred at $80^{\circ} \mathrm{C}$ for $16 \mathrm{~h}$ under $\mathrm{N}_{2}$. The reaction was diluted with saturated $\mathrm{NH}_{4} \mathrm{Cl}$ and extracted with MTBE (3 3400 $\mathrm{mL}$ ). The organic layers were combined, dried over anhydrous $\mathrm{Na}_{2} \mathrm{SO}_{4}$, filtered, and concentrated to dryness to yield the title compound (100 g, 92\% yield) as a brown oil.<smiles>Cc1cc(Oc2ccccc2)ccc1N</smiles>

Compound 33: 2-Methyl-4-phenoxyaniline. To a solution of 2-methyl-1-nitro-4-phenoxybenzene $(100 \mathrm{~g}, 436 \mathrm{mmol})$ in $\mathrm{EtOH} / \mathrm{H}_{2} \mathrm{O}(3: 1$ ratio, $2000 \mathrm{~mL})$ were sequentially added $\mathrm{NH}_{4} \mathrm{Cl}(117 \mathrm{~g}$, $2180 \mathrm{mmol})$ and $\mathrm{Fe}(97 \mathrm{~g}, 1700 \mathrm{mmol})$. The reaction mixture was heated to reflux for $2 \mathrm{~h}$, then the reaction was cooled to $25^{\circ} \mathrm{C}$ and concentrated to dryness. To the residue was added water and EtOAc and the organic layer was separated, washed with saturated $\mathrm{NaHCO}_{3}$ and saturated brine, dried over anhydrous $\mathrm{MgSO} 4$, filtered, and concentrated to dryness to yield the title compound ( $82 \mathrm{~g}, 90 \%$ yield). 
<smiles>Cc1cc(Oc2ccccc2)ccc1Nc1ccnc(Cl)c1C#N</smiles>

Compound 34: 2-Chloro-4-(2-methyl-4-phenoxyanilino)pyridine-3-carbonitrile. To a round bottom flask under a $\mathrm{N}_{2}$ atmosphere were added 2-methyl-4-phenoxyaniline (30 g, $150 \mathrm{mmol}$ ), 2chloro-4-iodopyridine-3-carbonitrile (51.6 g, $195 \mathrm{mmol})$, and dioxane (200 $\mathrm{mL})$, followed by bis(2-diphenylphosphinophenyl)ether (16 g, $30 \mathrm{mmol}), \mathrm{Pd}(\mathrm{OAc})_{2}(3.36 \mathrm{~g}, 15 \mathrm{mmol})$, and $\mathrm{K}_{3} \mathrm{PO}_{4}$ ( $89 \mathrm{~g}, 420 \mathrm{mmol}$ ). The reaction mixture was stirred at $100{ }^{\circ} \mathrm{C}$ overnight. The reaction mixture was filtered and purified $\mathrm{FCC}\left(\mathrm{SiO}_{2}, \mathrm{EtOAc} /\right.$ hexanes)to yield the title compound as a yellow solid (32 g, 63\% yield). MS (ESI): mass calcd. for $\mathrm{C}_{19} \mathrm{H}_{15} \mathrm{ClN}_{3} \mathrm{O}, 336.09[\mathrm{M}+\mathrm{H}]^{+} ; \mathrm{m} / \mathrm{z}$ found, 336.0.

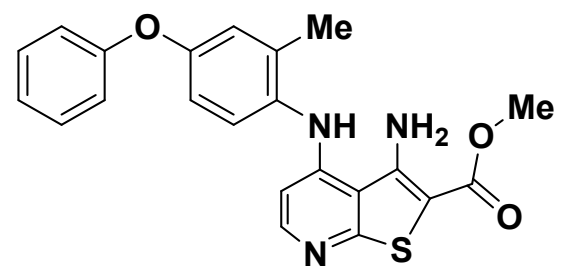

Compound 35: Methyl 3-amino-4-(2-methyl-4-phenoxyanilino)thieno[2,3- $b]$ pyridine-2carboxylate. To a round bottom flask were added 2-chloro-4-(2-methyl-4phenoxyanilino)pyridine-3-carbonitrile (36 g, $107 \mathrm{mmol})$ in $\mathrm{MeOH}(150 \mathrm{~mL})$. To this solution was added $\mathrm{NaOMe}(14.5 \mathrm{~g}, 268 \mathrm{mmol})$ in $\mathrm{MeOH}(30 \mathrm{~mL})$, followed by methyl 2-sulfanylacetate (23 g, $217 \mathrm{mmol}$ ). The reaction mixture was refluxed overnight. The reaction mixture was cooled, and the yellow precipitate was isolated by filtration, washed with $\mathrm{MeOH}$, and dried to yield the title compound as a yellow solid (30 g, 75\% yield). MS (ESI): mass calcd. for $\mathrm{C}_{22} \mathrm{H}_{20} \mathrm{~N}_{3} \mathrm{O}_{3} \mathrm{~S}[\mathrm{M}+\mathrm{H}]^{+}$ $406.12 ; \mathrm{m} / \mathrm{z}$ found, 406.1 .

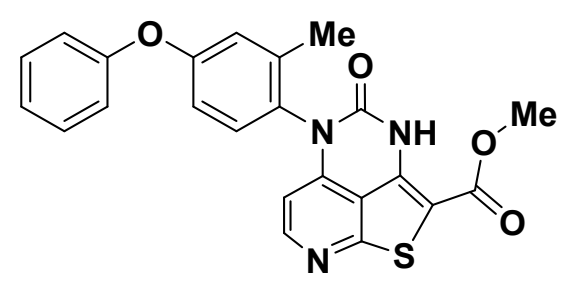

Compound 36: Methyl 5-(2-methyl-4-phenoxyphenyl)-4-oxo-4,5-dihydro-3H-1-thia-3,5,8triazaacenaphthylene-2-carboxylate. To a round bottom flask were added methyl 3-amino-4-(2- 
methyl-4-phenoxyanilino)thieno[2,3-b]pyridine-2-carboxylate (30.6 g, $75.5 \mathrm{mmol})$, carbonyl diimidazole $(49.0 \mathrm{~g}, 300 \mathrm{mmol})$, and 1,4-dioxane $(500 \mathrm{ml})$. The reaction was stirred at reflux overnight. Then the reaction mixture was concentrated to dryness and to the residue was added to $\mathrm{MeOH}(200 \mathrm{~mL})$ and the precipitate that formed was filtered off and dried to yield the title compound as a yellow solid (28.1 g, 86\% yield). MS (ESI): mass calcd. for $\mathrm{C}_{23} \mathrm{H}_{18} \mathrm{~N}_{3} \mathrm{O}_{4} \mathrm{~S}, 432.10$ $[\mathrm{M}+\mathrm{H}]^{+} ; \mathrm{m} / \mathrm{z}$ found, 432.1 .

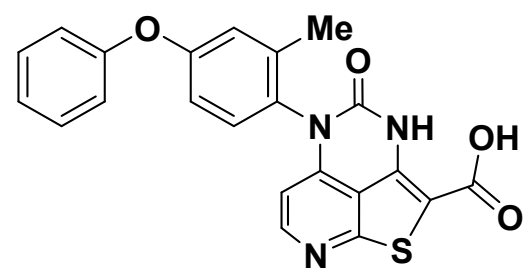

Compound 37: 5-(2-Methyl-4-phenoxyphenyl)-4-oxo-4,5-dihydro-3H-1-thia-3,5,8triazaacenaphthylene-2-carboxylic acid. To a round bottom flask were added methyl 5-(2-methyl4-phenoxyphenyl)-4-oxo-4,5-dihydro-3 $H$-1-thia-3,5,8-triazaacenaphthylene-2-carboxylate ( $9.2 \mathrm{~g}$, $21 \mathrm{mmol}$ ), lithium hydroxide (4.47 g, $106 \mathrm{mmol})$, THF (200 mL), $\mathrm{MeOH}(200 \mathrm{~mL})$, and $\mathrm{H}_{2} \mathrm{O}(50$ $\mathrm{mL}$ ). The reaction mixture was stirred at $50{ }^{\circ} \mathrm{C}$ for $15 \mathrm{~h}$. The mixture was concentrated to dryness and diluted with $\mathrm{H}_{2} \mathrm{O}$. The $\mathrm{pH}$ was adjusted to 2 with $1 \mathrm{M}$ aqueous $\mathrm{HCl}$ and the precipitate was filtered and dried to yield the title compound as yellow solid ( $8.10 \mathrm{~g}, 91 \%$ yield). MS (ESI): mass calcd. for $\mathrm{C}_{22} \mathrm{H}_{16} \mathrm{~N}_{3} \mathrm{O}_{4} \mathrm{~S}, 418.09[\mathrm{M}+\mathrm{H}]^{+} ; \mathrm{m} / \mathrm{z}$ found, 418.2.

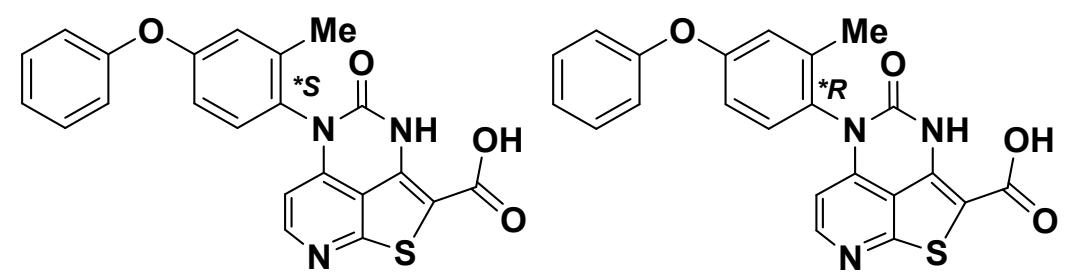

Compounds 38a and 38b: 5-(*S)-(2-Methyl-4-phenoxyphenyl)-4-oxo-4,5-dihydro-3H-1-thia3,5,8-triazaacenaphthylene-2-carboxylic acid. 5-(2-Methyl-4-phenoxyphenyl)-4-oxo-4,5dihydro-3H-1-thia-3,5,8-triazaacenaphthylene-2-carboxylic acid, as a mixture of atropisomers, was Was resolved on a chiral SFC column (Stationary phase: Whelk O1 $(S, S), 5 \mu \mathrm{m}, 250 \times 21.1 \mathrm{~mm}$ column. The mobile phase was: $40 \% \mathrm{CO}_{2}, 60 \% \mathrm{MeOH}(0.2 \%$ formic acid). The first eluting atropisomer arbitrarily labeled $* R$ and the second as $* \mathrm{~S}$, to indicate that the compound is a single 
atropisomer of unknown absolute configuration. MS (ESI): mass calcd. for $\mathrm{C}_{22} \mathrm{H}_{16} \mathrm{~N}_{3} \mathrm{O}_{4} \mathrm{~S}[\mathrm{M}+\mathrm{H}]^{+}$, $418.09 ; \mathrm{m} / \mathrm{z}$ found, 418.2 .

Compound 16: $(R)-N-(1-$ Acryloylpiperidin-3-yl)-5-(*R)-(2-methyl-4-phenoxyphenyl)-4-oxo-4,5dihydro-3H-1-thia-3,5,8-triazaacenaphthylene-2-carboxamide.

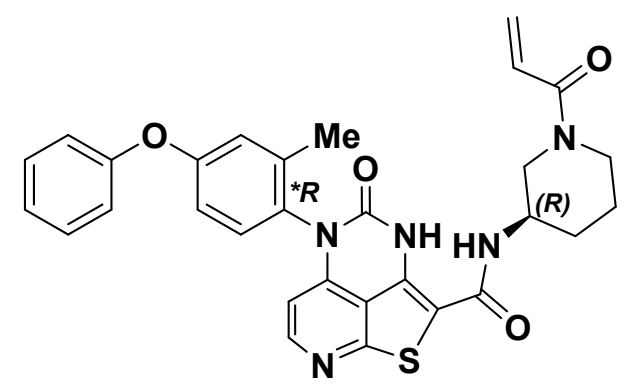

To a round bottom flask were added 5-(*R)-(2-methyl-4-phenoxyphenyl)-4-oxo-4,5-dihydro-3H1-thia-3,5,8-triazaacenaphthylene-2-carboxylic acid (100 mg, $0.24 \mathrm{mmol}$ ), DMF (3 mL), HATU (183 $\mathrm{mg}, 0.481 \mathrm{mmol})$, and TEA $(73 \mathrm{mg}, 0.72 \mathrm{mmol})$ and allowed to stir for $10 \mathrm{~min}$. $(R)-1-(3-$ aminopiperidin-1-yl)prop-2-en-1-one (55 $\mathrm{mg}, 0.29 \mathrm{mmol}$ ) was added and the mixture was stirred for 2 hours. The crude mixture was purified by $\mathrm{HPLC}\left(\mathrm{MeOH} / \mathrm{H}_{2} \mathrm{O}\right)$ to provide the desired compound as a slight yellow solid (30 mg, 32\%). MS (ESI): mass calcd. for $\mathrm{C}_{30} \mathrm{H}_{28} \mathrm{~N}_{5} \mathrm{O}_{4} \mathrm{~S}, 554.19$ $[\mathrm{M}+\mathrm{H}]^{+} ; \mathrm{m} / \mathrm{z}$ found, 554.0. ${ }^{1} \mathrm{H}$ NMR (400 MHz, DMSO- $\left.d_{6}\right): \delta$ 10.29-10.20 $(\mathrm{m}, 1 \mathrm{H}), 8.37-8.32(\mathrm{~m}$, 1H), 8.13-8.04 (m, 1H), 7.50-7.35 (m, 3H), 7.25-7.17 (m, 1H), 7.17-7.07 (m, 3H), 7.02-6.95 (m, $1 \mathrm{H}), 6.87-6.73(\mathrm{~m}, 1 \mathrm{H}), 6.16-6.06(\mathrm{~m}, 1 \mathrm{H}), 6.03-5.97(\mathrm{~m}, 1 \mathrm{H}), 5.72-5.64(\mathrm{~m}, 1 \mathrm{H})$, 4.54-4.18 (m, $1 \mathrm{H}), 4.10-3.95(\mathrm{~m}, 1 \mathrm{H}), 3.84-3.74(\mathrm{~m}, 1 \mathrm{H}), 3.17-2.92(\mathrm{~m}, 1 \mathrm{H}), 2.82-2.62(\mathrm{~m}, 1 \mathrm{H}), 2.07(\mathrm{~s}, 3 \mathrm{H})$, 2.00-1.88 (m, 1H), 1.84-1.74 (m, 1H), 1.74-1.61 (m, 1H), 1.51-1.36 (m, 1H). 


\section{General method 3: Compound 28}<smiles>Cc1cc(Oc2ccccc2)ccc1N1C(=O)Nc2c(C(=O)NC3CCN(C(=O)OC(C)(C)C)C3)sc3nccc1c23</smiles>

tert-Butyl

$(S)-3-(5-(* S)-(2-m e t h y l-4-p h e n o x y p h e n y 1)-4-o x o-4,5-d i h y d r o-3 H-1-t h i a-3,5,8-$

triazaacenaphthylene-2-carboxamido)pyrrolidine-1-carboxylate. To a stirred suspension of 5-(*S)(2-methyl-4-phenoxyphenyl)-4-oxo-4,5-dihydro-3H-1-thia-3,5,8-triazaacenaphthylene-2carboxylic acid (120 mg, $0.287 \mathrm{mmol})$ was added tert-butyl $(S)$-3-aminopyrrolidine-1-carboxylate (107 mg, $0.574 \mathrm{mmol})$, HATU (142 mg, $0.373 \mathrm{mmol})$, DIEA (55.3 $\mu \mathrm{L}, 0.574 \mathrm{mmol})$, and DMF (5 $\mathrm{mL}$ ). The resulting mixture was stirred for $1 \mathrm{~h}$ at room temperature. The solvent was removed, and the residue was partitioned between EtOAc and $\mathrm{H}_{2} \mathrm{O}$. The crude reaction mixture was by HPLC $\left(\mathrm{MeOH} / \mathrm{H}_{2} \mathrm{O}\right)$, yielding the title compound as a yellow solid (128 mg, 76\%). MS (ESI): mass calcd. for $\mathrm{C}_{31} \mathrm{H}_{32} \mathrm{~N}_{5} \mathrm{O}_{5} \mathrm{~S}, 586.21[\mathrm{M}+\mathrm{H}]^{+} ; \mathrm{m} / \mathrm{z}$ found, 586.3.<smiles></smiles>

$(S)-5-(* S)(2-M e t h y l-4-p h e n o x y p h e n y l)-4-o x o-N$-(pyrrolidin-3-yl)-4,5-dihydro-3H-1-thia-3,5,8triazaacenaphthylene-2-carboxamide. $\quad$ tert-Butyl $(S)-3-(5-(* S)(2-m e t h y l-4-p h e n o x y p h e n y)-4-$ oxo-4,5-dihydro-3H-1-thia-3,5,8-triazaacenaphthylene-2-carboxamido)pyrrolidine-1-carboxylate (128 mg, $0.219 \mathrm{mmol})$ in $\mathrm{MeOH}(3 \mathrm{~mL})$ was treated with a solution of concentrated aqueous $\mathrm{HCl}$ $(12 \mathrm{M}, 3 \mathrm{~mL})$. The mixture was stirred at room temperature for $1 \mathrm{~h}$. The solvent was evaporated, and the residue was purified by HPLC to afford the title compound as a yellow solid (111 $\mathrm{mg}$, 100\%). MS (ESI): mass calcd. for $\mathrm{C}_{26} \mathrm{H}_{24} \mathrm{~N}_{5} \mathrm{O}_{3} \mathrm{~S}[\mathrm{M}+\mathrm{H}]^{+}, 486.16 ; \mathrm{m} / \mathrm{z}$ found, 486.3 . 


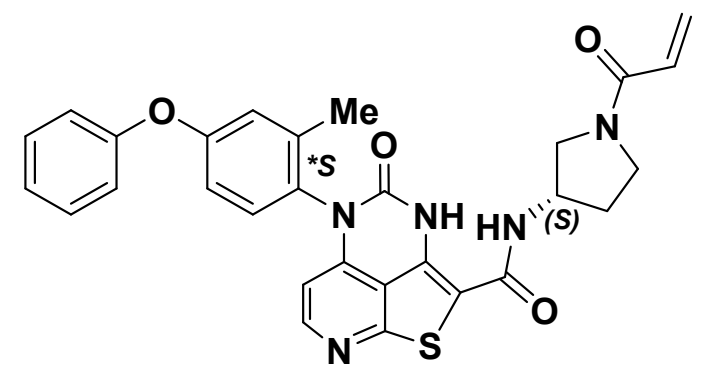

Compound 28: $(S)-N-(1-A c r y l o y l p y r r o l i d i n-3-y 1)-5-(* S)-(2-m e t h y l-4-p h e n o x y p h e n y l)-4-o x o-4,5-$ dihydro-3H-1-thia-3,5,8-triazaacenaphthylene-2-carboxamide. To a solution of $(S)-5(* S)-(2$ methyl-4-phenoxyphenyl)-4-oxo- $N$-(pyrrolidin-3-yl)-4,5-dihydro-3H-1-thia-3,5,8-

triazaacenaphthylene-2-carboxamide $(111 \mathrm{mg}, 0.229 \mathrm{mmol})$ in DCM $(10 \mathrm{ml})$ at $0{ }^{\circ} \mathrm{C}$ was added DIPEA (59.1 mg, $0.458 \mathrm{mmol})$, followed by acryloyl chloride (19 $\mathrm{mg}, 0.21 \mathrm{mmol})$. The reaction mixture was removed from the cooling bath and stirred for $1 \mathrm{~h}$. The mixture concentrated then purified by FCC ( $\left.\mathrm{SiO}_{2}, \mathrm{MeOH} / \mathrm{DCM}\right)$ to afford the title compound (55 mg, 44\%) as a white solid. MS (ESI): mass calcd. for $\mathrm{C}_{29} \mathrm{H}_{26} \mathrm{~N}_{5} \mathrm{O}_{4} \mathrm{~S}, 540.17[\mathrm{M}+\mathrm{H}]^{+}$; m/z found, 540.5. ${ }^{1} \mathrm{H}$ NMR (400 MHz, a mixture of DMSO- $d_{6}$ and $\left.\mathrm{CD}_{3} \mathrm{OD}\right): \delta 8.32-8.24(\mathrm{~m}, 1 \mathrm{H}), 7.42-7.35(\mathrm{~m}, 2 \mathrm{H}), 7.35-7.30(\mathrm{~m}, 1 \mathrm{H})$, 7.18-7.11 (m, 1H), 7.10-7.01 (m, 3H), 6.97-6.90 (m, 1H), 6.62-6.48 (m, 1H), 6.21-6.11 (m, 1H), 6.00-5.94 (m, 1H), 5.70-5.61 (m, 1H), 4.58-4.44 (m, 1H), 3.75-3.67 (m, 1H), 3.64-3.57 (m, 1H), 3.56-3.39 (m, 2H), 2.26-2.08 (m, 1H), 2.05 (s, 3H), 2.03-1.95 (m, 1H).

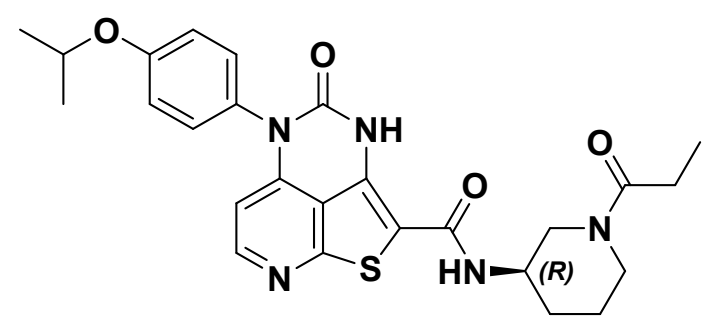

Compound 11: (R)-5-(4-Isopropoxyphenyl)-4-oxo- $N$-(1-propionylpiperidin-3-yl)-4,5-dihydro3H-1-thia-3,5,8-triazaacenaphthylene-2-carboxamide. $\quad$ To a solution of $(R)$-5-(4isopropoxyphenyl)-4-oxo- $N$-(piperidin-3-yl)-4,5-dihydro-3H-1-thia-3,5,8-triazaacenaphthylene2-carboxamide hydrochloride $(88.8 \mathrm{mg}, 0.182 \mathrm{mmol})$ in DCM $(1 \mathrm{~mL})$ was added TEA $(76 \mu \mathrm{L}$, $0.55 \mathrm{mmol})$. The resulting solution was cooled in an ice bath and propionyl chloride $(16 \mu \mathrm{L}, 0.18$ mmol) was added dropwise via a microliter syringe and the resulting orange solution was stirred 
under air in the ice bath for $25 \mathrm{~min}$. The reaction mixture was partitioned between DCM (10 mL) and saturated aqueous $\mathrm{NaHCO}_{3}(10 \mathrm{~mL})$. The aqueous phase was extracted once with EtOAc (10 $\mathrm{mL}$ ) and the combined organic extracts were dried over anhydrous $\mathrm{Na}_{2} \mathrm{SO}_{4}$, filtered, and concentrated to dryness. The residue was purified by $\mathrm{FCC}\left(\mathrm{SiO}_{2}, \mathrm{EtOAc} /\right.$ hexanes $)$ to give the title compound as a light-yellow powder (41.5 mg, $45 \%$ ). MS (ESI): mass calcd. for $\mathrm{C}_{26} \mathrm{H}_{30} \mathrm{~N}_{5} \mathrm{O}_{4} \mathrm{~S}$, 508.20 $[\mathrm{M}+\mathrm{H}]^{+} ; \mathrm{m} / \mathrm{z}$ found, 508.3. ${ }^{1} \mathrm{H}$ NMR $\left(400 \mathrm{MHz}\right.$, DMSO- $d_{6}, 1: 1$ mixture of rotamers): $\delta 10.18(\mathrm{~s}, 0.5 \mathrm{H}), 10.12(\mathrm{~s}, 0.5 \mathrm{H}), 8.33(\mathrm{~d}, J=5.56 \mathrm{~Hz}, 1 \mathrm{H}), 8.10(\mathrm{~d}, J=7.07 \mathrm{~Hz}, 0.5 \mathrm{H})$, $8.02(\mathrm{~d}, J=7.58 \mathrm{~Hz}, 0.5 \mathrm{H}), 7.34(\mathrm{~d}, J=9.09 \mathrm{~Hz}, 2 \mathrm{H}), 7.10(\mathrm{~d}, J=9.09 \mathrm{~Hz}, 2 \mathrm{H}), 6.01-6.05(\mathrm{~m}$, 1H), 4.70 (spt, $J=5.98 \mathrm{~Hz}, 1 \mathrm{H}), 4.33-4.50(\mathrm{~m}, 0.5 \mathrm{H}), 4.19-4.27$ (m, 0.5H), 3.70-3.95 (m, 2H), 2.86-3.02 (m, 1H), 2.53-2.68 (m, $1 \mathrm{H}), 2.30-2.38(\mathrm{~m}, 2 \mathrm{H}), 1.87-1.97(\mathrm{~m}, 1 \mathrm{H}), 1.35-1.80(\mathrm{~m}, 3 \mathrm{H})$, $1.33(\mathrm{~d}, J=6.06 \mathrm{~Hz}, 6 \mathrm{H}), 1.01(\mathrm{q}, J=7.07 \mathrm{~Hz}, 3 \mathrm{H})$.

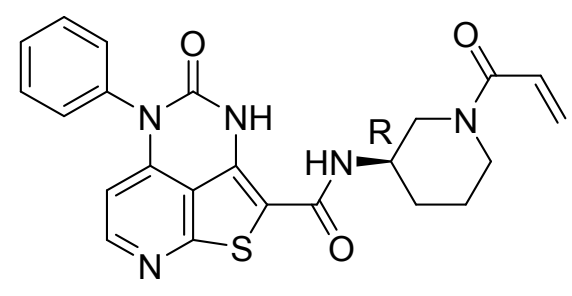

Compound 12: $(R)$-N-(1-acryloylpiperidin-3-yl)-4-oxo-5-phenyl-4,5-dihydro-3H-1-thia-3,5,8triazaacenaphthylene-2-carboxamide. Compound 12 was prepared using general method 3. MS (ESI): mass calcd. for $\mathrm{C}_{23} \mathrm{H}_{22} \mathrm{~N}_{5} \mathrm{O}_{3} \mathrm{~S}, 448.14[\mathrm{M}+\mathrm{H}]^{+} ; \mathrm{m} / \mathrm{z}$ found, 447.9. ${ }^{1} \mathrm{H}$ NMR (400 MHz, DMSO- $\left.d_{6}\right): \delta 10.20(\mathrm{~d}, \mathrm{~J}=14.4 \mathrm{~Hz}, 1 \mathrm{H}), 8.33(\mathrm{~d}, \mathrm{~J}=5.5 \mathrm{~Hz}, 1 \mathrm{H}), 8.16-8.04(\mathrm{~m}, 1 \mathrm{H}), 7.64-7.60$ (m, 2H), 7.57-7.54 (m, 1H), 7.48 (d, J = 7.1 Hz, 2H), 6.87-6.75 (m, 1H), 6.12 (d, J = 16.7 Hz, 1H), $5.99(\mathrm{~d}, \mathrm{~J}=5.5 \mathrm{~Hz}, 1 \mathrm{H}), 5.70(\mathrm{~d}, \mathrm{~J}=10.7 \mathrm{~Hz}, 1 \mathrm{H}), 4.50-4.21(\mathrm{~m}, 1 \mathrm{H}), 4.08-3.99(\mathrm{~m}, 1 \mathrm{H}), 3.79(\mathrm{~s}$, $1 \mathrm{H}), 3.17-2.94(\mathrm{~m}, 1 \mathrm{H}), 2.77-2.64(\mathrm{~m}, 1 \mathrm{H}), 1.97-1.94(\mathrm{~m}, 1 \mathrm{H}), 1.81-1.78(\mathrm{~m}, 1 \mathrm{H}), 1.74-1.57(\mathrm{~m}$, 1H), 1.43 (brs, $1 \mathrm{H})$. 


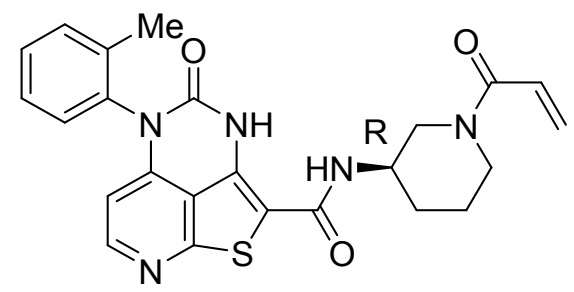

Compound 13: $(R)-N$-(1-Acryloylpiperidin-3-yl)-4-oxo-5-(o-tolyl)-4,5-dihydro-3H-1-thia-3,5,8triazaacenaphthylene-2-carboxamide. Compound 13 was prepared using general method 3. MS (ESI): mass calcd. for $\mathrm{C}_{24} \mathrm{H}_{24} \mathrm{~N}_{5} \mathrm{O}_{3} \mathrm{~S}, 462.16[\mathrm{M}+\mathrm{H}]^{+} ; \mathrm{m} / \mathrm{z}$ found, 462.1. ${ }^{1} \mathrm{H}$ NMR (400 MHz, $\left.\mathrm{CD}_{3} \mathrm{OD}\right): \delta 8.29(\mathrm{~d}, J=5.5,1 \mathrm{H}), 7.48-7.39(\mathrm{~m}, 3 \mathrm{H}), 7.35-7.30(\mathrm{~m}, 1 \mathrm{H}), 6.86-6.71(\mathrm{~m}, 1 \mathrm{H}), 6.25-$ $6.14(\mathrm{~m}, 1 \mathrm{H}), 5.96(\mathrm{~d}, J=5.5,1 \mathrm{H}), 5.76-5.67(\mathrm{~m}, 1 \mathrm{H}), 4.56-4.26(\mathrm{~m}, 1 \mathrm{H}), 4.21-3.90(\mathrm{~m}, 2 \mathrm{H}), 3.20-$ $3.11(\mathrm{~m}, 1 \mathrm{H}), 2.65-2.82(\mathrm{~m}, 1 \mathrm{H}), 2.16(\mathrm{~s}, 3 \mathrm{H}), 2.09-2.01(\mathrm{~m}, 1 \mathrm{H}), 1.90-1.82(\mathrm{~m}, 1 \mathrm{H}), 1.80-1.22$ $(\mathrm{m}, 1 \mathrm{H}), 1.63-1.52(\mathrm{~m}, 1 \mathrm{H})$.

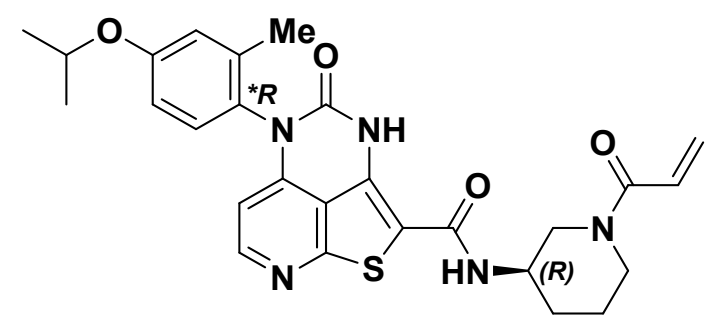

Compound 14, Step G: $(R)-N-(1-$ Acryloylpiperidin-3-yl)-5-(*R)-(4-isopropoxy-2-methylphenyl)4-oxo-4,5-dihydro-3H-1-thia-3,5,8-triazaacenaphthylene-2-carboxamide. Compound 13 was prepared using general method 3. MS (ESI): mass calcd. for $\mathrm{C}_{27} \mathrm{H}_{30} \mathrm{~N}_{5} \mathrm{O}_{4} \mathrm{~S}, 520.20[\mathrm{M}+\mathrm{H}]^{+} ; \mathrm{m} / \mathrm{z}$ found, 520.2. ${ }^{1} \mathrm{H}$ NMR $\left(400 \mathrm{MHz}, \mathrm{CD}_{3} \mathrm{OD}\right): \delta 8.31(\mathrm{~d}, J=5.56 \mathrm{~Hz}, 1 \mathrm{H}), 7.21(\mathrm{~d}, J=8.59 \mathrm{~Hz}, 1 \mathrm{H})$, $6.98(\mathrm{~d}, J=3.03 \mathrm{~Hz}, 1 \mathrm{H}), 6.92(\mathrm{dd}, J=2.53,8.59 \mathrm{~Hz}, 1 \mathrm{H}), 6.80(\mathrm{ddd}, J=6.57,10.48,16.80 \mathrm{~Hz}$, 1H), $6.21(\mathrm{~d}, J=16.67 \mathrm{~Hz}, 1 \mathrm{H}), 6.03(\mathrm{~d}, J=5.56 \mathrm{~Hz}, 1 \mathrm{H}), 5.74(\mathrm{dd}, J=4.55,10.61 \mathrm{~Hz}, 1 \mathrm{H}), 4.67$ (spt, $J=6.06 \mathrm{~Hz}, 1 \mathrm{H}), 4.49-4.59$ (m, 0.5H), 4.25-4.37 (m, 0.5H), 4.14-4.23 (m, 0.5H), 3.89-4.05 (m, 1.5H), 3.11-3.23 (m, 1H), 2.83-2.98 (m, 1H), $2.12(\mathrm{~s}, 3 \mathrm{H}), 2.02-2.10(\mathrm{~m}, 1 \mathrm{H}), 1.88(\mathrm{dt}, J=$ $3.66,13.39 \mathrm{~Hz}, 1 \mathrm{H}), 1.49-1.82(\mathrm{~m}, 2 \mathrm{H}), 1.35$ (d, $J=6.06 \mathrm{~Hz}, 6 \mathrm{H})$. 


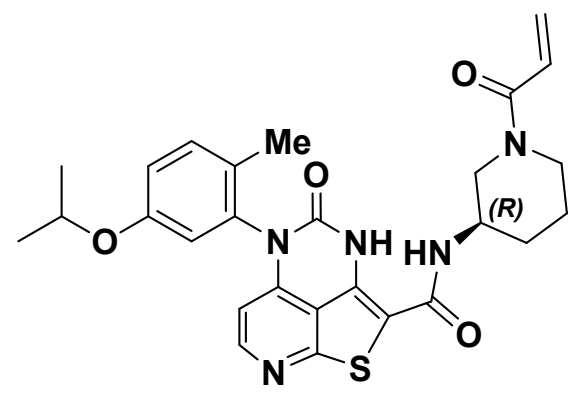

Compound 15: (R)-N-(1-Acryloylpiperidin-3-yl)-5-(5-isopropoxy-2-methylphenyl)-4-oxo-4,5dihydro-3H-1-thia-3,5,8-triazaacenaphthylene-2-carboxamide. Compound 13 was prepared using general method 1. MS (ESI): mass calcd. for $\mathrm{C}_{27} \mathrm{H}_{30} \mathrm{~N}_{5} \mathrm{O}_{4} \mathrm{~S}[\mathrm{M}+\mathrm{H}]^{+}, 520.20 ; \mathrm{m} / \mathrm{z}$ found, 520.1. ${ }^{1} \mathrm{H}$ NMR (600 MHz, CD $\left.{ }_{3} \mathrm{OD}\right): \delta 8.34-8.28(\mathrm{~d}, J=5.6 \mathrm{~Hz}, 1 \mathrm{H}), 7.37-7.31$ (d, $\left.J=8.5 \mathrm{~Hz}, 1 \mathrm{H}\right), 7.04-$ $6.99(\mathrm{~m}, 1 \mathrm{H}), 6.96-6.91(\mathrm{~d}, J=2.8 \mathrm{~Hz}, 1 \mathrm{H}), 6.84-6.74(\mathrm{~m}, 1 \mathrm{H}), 6.25-6.16(\mathrm{~m}, 1 \mathrm{H}), 6.05-6.01(\mathrm{~m}$, $1 \mathrm{H}), 5.77-5.70(\mathrm{~m}, 1 \mathrm{H}), 4.63-4.56(\mathrm{~m}, 1 \mathrm{H}), 4.55-4.26(\mathrm{~m}, 1 \mathrm{H}), 4.22-3.92(\mathrm{~m}, 2 \mathrm{H}), 3.23-3.14(\mathrm{~m}$, 1H), 2.99-2.85 (m, 1H), 2.11-2.05 (s, 4H), 1.92-1.83 (m, 1H), 1.81-1.68 (m, 1H), 1.65-1.49 (m, $1 \mathrm{H}), 1.32-1.29(\mathrm{~s}, 6 \mathrm{H})$.

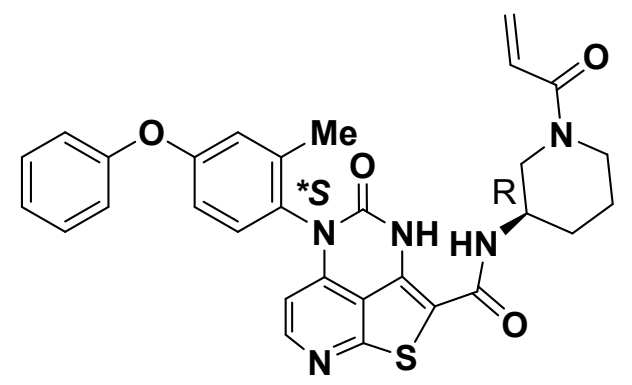

Compound 17: $(R)-N$-(1-Acryloylpiperidin-3-yl)-5- $(* S)-(2-m e t h y l-4-p h e n o x y p h e n y l)-4-0 x o-4,5-$ dihydro-3H-1-thia-3,5,8-triazaacenaphthylene-2-carboxamide. Compound 17 was prepared using general method 2. MS (ESI): mass calcd. for $\mathrm{C}_{30} \mathrm{H}_{28} \mathrm{~N}_{5} \mathrm{O}_{4} \mathrm{~S}[\mathrm{M}+\mathrm{H}]^{+}, 554.19 ; \mathrm{m} / \mathrm{z}$ found, 554.5. ${ }^{1} \mathrm{H}$ NMR (400 MHz, DMSO- $\left.d_{6}\right): \delta$ 10.29-10.20 (m, 1H), 8.37-8.32 (m, 1H), 8.13-8.04 (m, 1H), 7.50$7.35(\mathrm{~m}, 3 \mathrm{H}), 7.25-7.17(\mathrm{~m}, 1 \mathrm{H})$, 7.17-7.07 (m, 3H), 7.02-6.95 (m, 1H), 6.87-6.73 (m, 1H), 6.16$6.06(\mathrm{~m}, 1 \mathrm{H}), 6.03-5.97(\mathrm{~m}, 1 \mathrm{H}), 5.72-5.64(\mathrm{~m}, 1 \mathrm{H}), 4.54-4.18(\mathrm{~m}, 1 \mathrm{H}), 4.10-3.95(\mathrm{~m}, 1 \mathrm{H}), 3.84-$ $3.74(\mathrm{~m}, 1 \mathrm{H}), 3.17-2.92(\mathrm{~m}, 1 \mathrm{H}), 2.82-2.62(\mathrm{~m}, 1 \mathrm{H}), 2.07(\mathrm{~s}, 3 \mathrm{H}), 2.00-1.88(\mathrm{~m}, 1 \mathrm{H}), 1.84-1.74$ (m, 1H), 1.74-1.61 (m, 1H), 1.51-1.36 (m, 1H). 


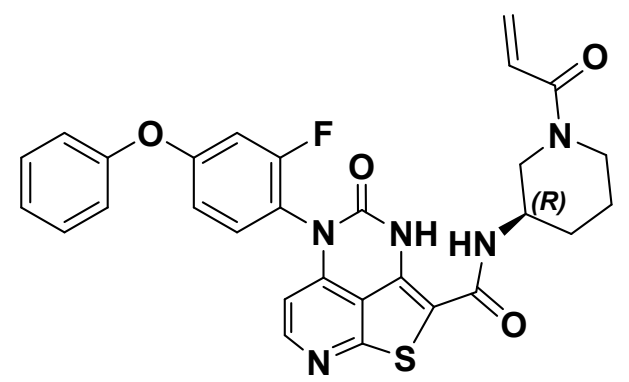

Compound 18: $(R)-N$-(1-Acryloylpiperidin-3-yl)-5-(2-fluoro-4-phenoxyphenyl)-4-oxo-4,5dihydro-3H-1-thia-3,5,8-triazaacenaphthylene-2-carboxamide. Compound 18 was prepared using general method 3. MS (ESI): mass calcd. for $\mathrm{C}_{29} \mathrm{H}_{25} \mathrm{FN}_{5} \mathrm{O}_{4} \mathrm{~S}, 558.16 ; \mathrm{m} / \mathrm{z}$ found, $558.2[\mathrm{M}+\mathrm{H}]^{+}$. ${ }^{1} \mathrm{H}$ NMR (400 MHz, DMSO- $\left.d_{6}\right)$ : $\delta 10.37$ (s, $\left.1 \mathrm{H}\right), 8.33$ (d, $\left.J=5.4 \mathrm{~Hz}, 1 \mathrm{H}\right), 8.22-8.05$ (m, 1H), 7.64$7.51(\mathrm{~m}, 1 \mathrm{H}), 7.51-7.38(\mathrm{~m}, 2 \mathrm{H}), 7.28-7.20(\mathrm{~m}, 1 \mathrm{H}), 7.20-7.09$ (m, 3H), 6.99-6.90 (m, 1H), 6.86$6.63(\mathrm{~m}, 1 \mathrm{H}), 6.17(\mathrm{~d}, J=5.4 \mathrm{~Hz}, 1 \mathrm{H}), 6.07(\mathrm{~d}, J=16.6 \mathrm{~Hz}, 1 \mathrm{H}), 5.65(\mathrm{~d}, J=11.1 \mathrm{~Hz}, 1 \mathrm{H}), 4.53-$ $4.07(\mathrm{~m}, 1 \mathrm{H}), 4.08-3.88(\mathrm{~m}, 1 \mathrm{H}), 3.84-3.65(\mathrm{~m}, 1 \mathrm{H}), 3.11-2.91(\mathrm{~m}, 1 \mathrm{H}), 2.78-2.56(\mathrm{~m}, 1 \mathrm{H}), 2.00-$ $1.83(\mathrm{~m}, 1 \mathrm{H}), 1.80-1.69(\mathrm{~m}, 1 \mathrm{H}), 1.68-1.54(\mathrm{~m}, 1 \mathrm{H}), 1.47-1.30(\mathrm{~m}, 1 \mathrm{H})$.

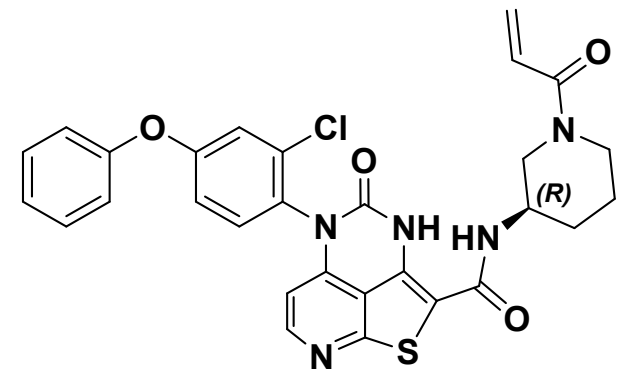

Compound 19: (R)- $N$-(1-Acryloylpiperidin-3-yl)-5-(2-chloro-4-phenoxyphenyl)-4-oxo-4,5dihydro-3H-1-thia-3,5,8-triazaacenaphthylene-2-carboxamide. Compound 19 was prepared using general method 3. MS (ESI): mass calcd. for $\mathrm{C}_{29} \mathrm{H}_{25} \mathrm{ClN}_{5} \mathrm{O}_{4} \mathrm{~S}[\mathrm{M}+\mathrm{H}]^{+}, 574.13 ; \mathrm{m} / \mathrm{z}$ found, 574.3. ${ }^{1} \mathrm{H}$ NMR (400 MHz, CD3OD): $\delta 8.33$ (d, J = 5.6 Hz, 1H), 7.78-7.73 (m, 1H), 7.52-7.45 (m, 1H), 7.36-7.21 (m, 2H), 7.10-7.02 (m, 2H), 7.00-6.88 (m, 2H), 6.88-6.70 (m, 1H), 6.28-6.14 (m, 1H), $6.07(\mathrm{~d}, \mathrm{~J}=5.6 \mathrm{~Hz}, 1 \mathrm{H}), 5.81-5.66(\mathrm{~m}, 1 \mathrm{H}), 4.63-3.87(\mathrm{~m}, 3 \mathrm{H}), 3.25-3.10(\mathrm{~m}, 1 \mathrm{H}), 3.01-2.82(\mathrm{~m}$, 1H), 2.14 (s, 3H), 2.09-2.01 (m, 1H), 1.94-1.83 (m, 1H), 1.81-1.68 (m, 1H), 1.65-1.52 (m, 1H). 


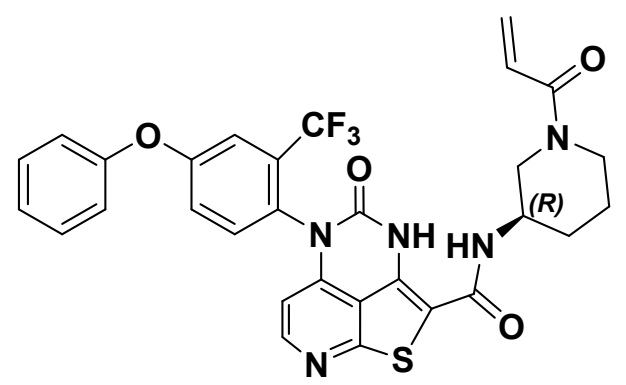

Compound

$(R)-N$-(1-Acryloylpiperidin-3-yl)-4-oxo-5-(4-phenoxy-2-

(trifluoromethyl)phenyl)-4,5-dihydro-3H-1-thia-3,5,8-triazaacenaphthylene-2-carboxamide. $608.16[\mathrm{M}+\mathrm{H}]^{+} ; \mathrm{m} / \mathrm{z}$ found, 608.3. ${ }^{1} \mathrm{H}$ NMR $\left(400 \mathrm{MHz}, \mathrm{DMSO}-d_{6}\right): \delta 10.38(\mathrm{~s}, 1 \mathrm{H}), 8.34(\mathrm{~d}, J=$ $5.5 \mathrm{~Hz}, 1 \mathrm{H}), 8.20-8.02(\mathrm{~m}, 1 \mathrm{H}), 7.74(\mathrm{~d}, J=8.7 \mathrm{~Hz}, 1 \mathrm{H}), 7.59-7.38(\mathrm{~m}, 4 \mathrm{H}), 7.35-7.14(\mathrm{~m}, 3 \mathrm{H})$, 6.90-6.65 (m, 1H), 6.20-6.00 (m, 2H), $5.66(\mathrm{~d}, J=12.2 \mathrm{~Hz}, 1 \mathrm{H}), 4.52-4.12(\mathrm{~m}, 1 \mathrm{H}), 4.10-3.89(\mathrm{~m}$, $1 \mathrm{H}), 3.84-3.63(\mathrm{~m}, 1 \mathrm{H}), 3.16-2.88(\mathrm{~m}, 1 \mathrm{H}), 2.83-2.55(\mathrm{~m}, 1 \mathrm{H}), 2.05-1.85(\mathrm{~m}, 1 \mathrm{H}), 1.85-1.51(\mathrm{~m}$, $2 \mathrm{H}), 1.50-1.30(\mathrm{~m}, 1 \mathrm{H})$.

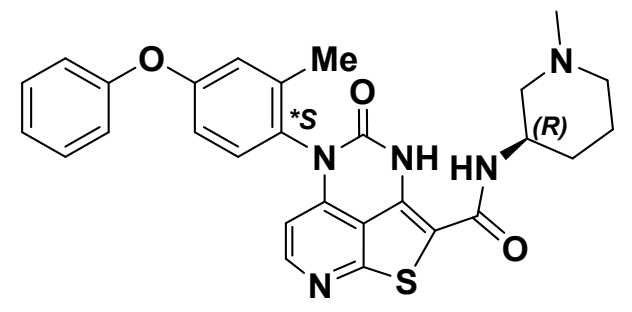

Compound 21: $(R)-5-(* S)$-(2-Methyl-4-phenoxyphenyl)- $N$-(1-methylpiperidin-3-yl)-4-oxo-4,5dihydro-3H-1-thia-3,5,8-triazaacenaphthylene-2-carboxamide. To a stirred suspension of 5-(*S)(2-methyl-4-phenoxyphenyl)-4-oxo-4,5-dihydro-3 $H$-1-thia-3,5,8-triazaacenaphthylene-2carboxylic acid (150 mg, $0.359 \mathrm{mmol})$ was added $(R)$-1-methylpiperidin-3-amine (81 mg, 0.54 mmol), HATU (164 mg, $0.43 \mathrm{mmol}$ ), DIEA (0.15 mL, $1.077 \mathrm{mmol})$, and DMF (3 mL). The resulting mixture was stirred at room temperature overnight, then purified by $\mathrm{HPLC}\left(\mathrm{MeOH} / \mathrm{H}_{2} \mathrm{O}\right)$, yielding the title compound as a yellow solid (102 mg, 55\%). MS (ESI): mass calcd. for $\mathrm{C}_{28} \mathrm{H}_{28} \mathrm{~N}_{5} \mathrm{O}_{3} \mathrm{~S}, 514.19[\mathrm{M}+\mathrm{H}]^{+} ; \mathrm{m} / \mathrm{z}$ found, 514.2. ${ }^{1} \mathrm{H} \mathrm{NMR}\left(400 \mathrm{MHz}, \mathrm{CD}_{3} \mathrm{OD}\right): \delta 8.30(\mathrm{~d}, \mathrm{~J}=$ 5.6, 1H), 7.43-7.35 (m, 2H), 7.31-7.26 (m, 1H), 7.20-7.14 (m, 1H), 7.12-7.08 (m, 2H), 7.08-7.03 (m, 1H), 7.01-6.95 (m, 1H), $6.05(\mathrm{~d}, \mathrm{~J}=5.6,1 \mathrm{H}), 4.24-4.11(\mathrm{~m}, 1 \mathrm{H}), 3.02-2.90(\mathrm{~m}, 1 \mathrm{H}), 2.78-2.68$ 
(m, 1H), $2.36(\mathrm{~s}, 3 \mathrm{H}), 2.29-2.16(\mathrm{~m}, 2 \mathrm{H}), 2.12(\mathrm{~s}, 3 \mathrm{H}), 1.95-1.78(\mathrm{~m}, 2 \mathrm{H}), 1.74-1.63(\mathrm{~m}, 1 \mathrm{H}), 1.57-$ $1.45(\mathrm{~m}, 1 \mathrm{H})$.

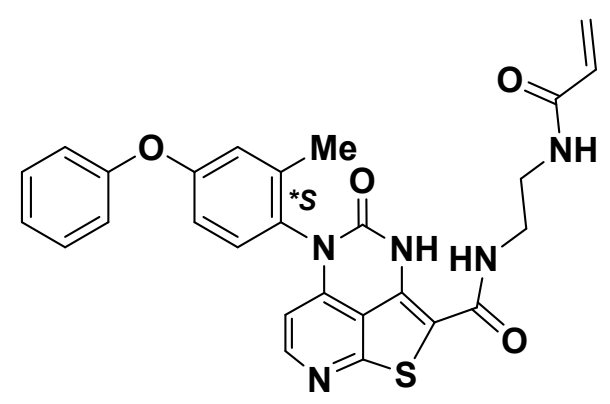

Compound 25: $N$-(2-Acrylamidoethyl)-5-(*S)-(2-methyl-4-phenoxyphenyl)-4-oxo-4,5-dihydro3H-1-thia-3,5,8-triazaacenaphthylene-2-carboxamide. Compound 25 was prepared using general method 3. MS (ESI): mass calcd. for $\mathrm{C}_{27} \mathrm{H}_{24} \mathrm{~N}_{5} \mathrm{O}_{4} \mathrm{~S}, 514.15[\mathrm{M}+\mathrm{H}]^{+} ; \mathrm{m} / \mathrm{z}$ found, 514.1. ${ }^{1} \mathrm{H}$ NMR (400 MHz, $\left.\mathrm{CD}_{3} \mathrm{OD}\right) \delta 8.31-8.20(\mathrm{~m}, 1 \mathrm{H}), 7.42-7.35(\mathrm{~m}, 2 \mathrm{H}), 7.30-7.23(\mathrm{~m}, 1 \mathrm{H}), 7.19-7.14(\mathrm{~m}$, 1H), 7.10-7.02 (m, 3H), 6.99-6.93 (m, 1H), 6.28-6.19 (m, 2H), 6.06-5.98 (m, 1H), 5.68-5.61 (m, $1 \mathrm{H}), 3.53-3.45(\mathrm{~m}, 4 \mathrm{H}), 2.11(\mathrm{~s}, 3 \mathrm{H})$.

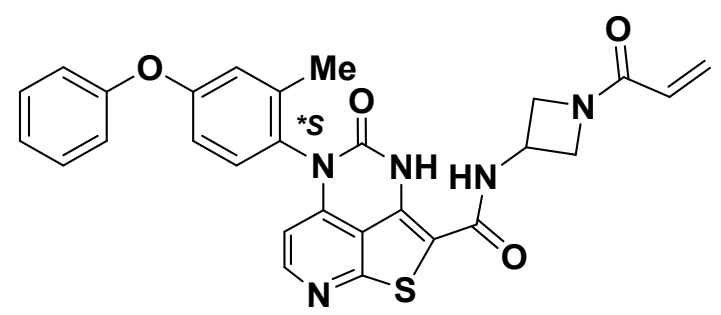

Compound 26: $\quad N$-(1-Acryloylazetidin-3-yl)-5-(*S)-(2-methyl-4-phenoxyphenyl)-4-oxo-4,5dihydro-3H-1-thia-3,5,8-triazaacenaphthylene-2-carboxamide. Compound 26 was prepared using general method 3. MS (ESI): mass calcd. for $\mathrm{C}_{28} \mathrm{H}_{24} \mathrm{~N}_{5} \mathrm{O}_{4} \mathrm{~S}, 526.15[\mathrm{M}+\mathrm{H}]^{+} ; \mathrm{m} / \mathrm{z}$ found, 526.1. ${ }^{1} \mathrm{H}$ NMR (400 MHz, DMSO- $d_{6}$ and $\left.\mathrm{CD}_{3} \mathrm{OD}\right): \delta 8.29$ (d, $\left.J=5.5 \mathrm{~Hz}, 1 \mathrm{H}\right), 7.43-7.33(\mathrm{~m}, 2 \mathrm{H}), 7.31-7.23$ (m, 1H), 7.17-7.09 (m, 1H), 7.08-6.98 (m, 3H), 6.97-6.89 (m, 1H), 6.37-6.23 (m, 1H), 6.20-6.08 (m, 1H), $5.98(\mathrm{~d}, J=5.5 \mathrm{~Hz}, 1 \mathrm{H}), 5.71-5.60(\mathrm{~m}, 1 \mathrm{H}), 4.81-4.69(\mathrm{~m}, 1 \mathrm{H}), 4.58-4.47(\mathrm{~m}, 1 \mathrm{H}), 4.24-$ $4.17(\mathrm{~m}, 2 \mathrm{H}), 4.04-3.97(\mathrm{~m}, 1 \mathrm{H}), 2.04(\mathrm{~s}, 3 \mathrm{H})$. 


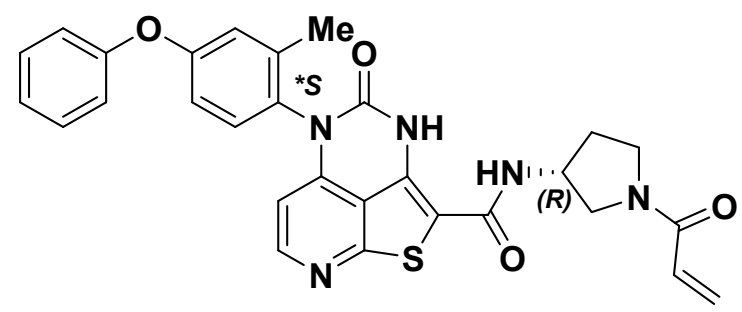

Compound 27: (R)-N-(1-Acryloylpyrrolidin-3-yl)-5-(*S)-(2-methyl-4-phenoxyphenyl)-4-oxo4,5-dihydro-3H-1-thia-3,5,8-triazaacenaphthylene-2-carboxamide. To a round bottom flask were added 5-(*S)-(2-methyl-4-phenoxyphenyl)-4-oxo-4,5-dihydro-3H-1-thia-3,5,8triazaacenaphthylene-2-carboxylic acid (200 mg, $0.48 \mathrm{mmol}$ ), DMF (5 mL), HATU (237 mg, 0.62 mmol), and DIEA (155 mg, $1.2 \mathrm{mmol})$ and allowed to stir. After 5 minutes, $(R)-1-(3-$ aminopyrrolidin-1-yl)prop-2-en-1-one (169 mg, $0.96 \mathrm{mmol})$ was added portion wise and the mixture was stirred for 1 hour. The reaction was quenched with $\mathrm{H}_{2} \mathrm{O}$ and the ppt was filtered and dried. The resulting solid was purified by $\mathrm{FCC}$ ( $\mathrm{SiO}_{2}$, EtOAc/hexanes)to give the title compound as a white solid ( $83 \mathrm{mg}, 32 \%$ ). HRMS calculated for $\mathrm{C}_{29} \mathrm{H}_{26} \mathrm{~N}_{5} \mathrm{O}_{4} \mathrm{~S} 540.1706$, found $540.1701 .{ }^{1} \mathrm{H}$ NMR (400 MHz, DMSO- $\left.d_{6}\right): \delta 10.24$ (s, 1H), 8.43-8.22 (m, 2H), 7.57-7.29 (m, 3H), 7.25-7.04 (m, 4H), 7.03-6.90 (m, 1H), 6.70-6.45 (m, 1H), $6.13(\mathrm{~d}, J=16.4 \mathrm{~Hz}, 1 \mathrm{H}), 6.05-6.88(\mathrm{~m}, 1 \mathrm{H}), 5.73-$ $5.57(\mathrm{~m}, 1 \mathrm{H}), 4.60-4.30(\mathrm{~m}, 1 \mathrm{H}), 3.91-3.36(\mathrm{~m}, 4 \mathrm{H}), 2.24-1.89(\mathrm{~m}, 5 \mathrm{H})$.

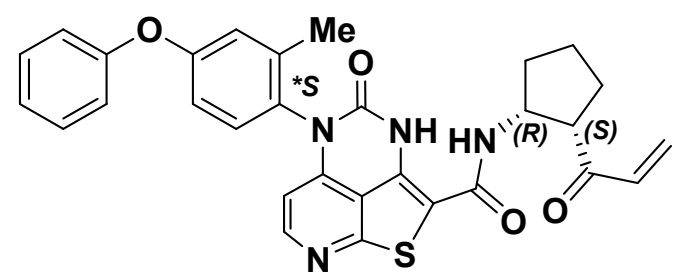

Compound 29: $\quad N-((1 R, 2 S)-2-A c r y l a m i d o c y c l o p e n t y l)-5-(* S)-(2-m e t h y l-4-p h e n o x y p h e n y l)-4-$ oxo-4,5-dihydro-3H-1-thia-3,5,8-triazaacenaphthylene-2-carboxamide. Compound 29 was prepared using general method 3. MS (ESI): mass calcd. for $\mathrm{C}_{30} \mathrm{H}_{28} \mathrm{~N}_{5} \mathrm{O}_{4} \mathrm{~S}[\mathrm{M}+\mathrm{H}]^{+} 554.19 ; \mathrm{m} / \mathrm{z}$ found, 554.5. ${ }^{1} \mathrm{H}$ NMR (400 MHz, $\left.\mathrm{CD}_{3} \mathrm{OD}\right): \delta 8.30$ (d, $\left.J=5.6 \mathrm{~Hz}, 1 \mathrm{H}\right), 7.44-7.33$ (m, 2H), 7.30$7.24(\mathrm{~m}, 1 \mathrm{H}), 7.20-7.13(\mathrm{~m}, 1 \mathrm{H}), 7.12-7.02(\mathrm{~m}, 3 \mathrm{H}), 7.00-6.92(\mathrm{~m}, 1 \mathrm{H}), 6.31-6.14(\mathrm{~m}, 2 \mathrm{H}), 6.04$ $(\mathrm{d}, J=5.6 \mathrm{~Hz}, 1 \mathrm{H}), 5.65-5.56(\mathrm{~m}, 1 \mathrm{H}), 4.48-4.33(\mathrm{~m}, 2 \mathrm{H}), 2.17-2.03(\mathrm{~m}, 5 \mathrm{H}), 1.95-1.85(\mathrm{~m}, 1 \mathrm{H})$, $1.80-1.60(\mathrm{~m}, 3 \mathrm{H})$. 


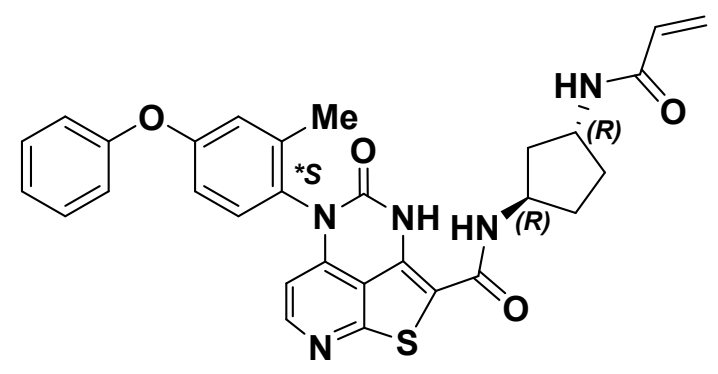

Compound 30: $N$-((1R,3R)-3-Acrylamidocyclopentyl)-5-(*S)-(2-methyl-4-phenoxyphenyl)-4oxo-4,5-dihydro-3H-1-thia-3,5,8-triazaacenaphthylene-2-carboxamide. Compound 30 was prepared using general method 3. MS (ESI): mass calcd. for $\mathrm{C}_{30} \mathrm{H}_{28} \mathrm{~N}_{5} \mathrm{O}_{4} \mathrm{~S}[\mathrm{M}+\mathrm{H}]^{+}, 554.19 ; \mathrm{m} / \mathrm{z}$ found, 554.4. ${ }^{1} \mathrm{H}$ NMR (400 MHz, $\left.\mathrm{CD}_{3} \mathrm{OD}\right): \delta 8.31(\mathrm{~d}, J=5.6 \mathrm{~Hz}, 1 \mathrm{H}), 7.43-7.35(\mathrm{~m}, 2 \mathrm{H}), 7.33-$ $7.24(\mathrm{~m}, 1 \mathrm{H}), 7.18-7.12(\mathrm{~m}, 1 \mathrm{H}), 7.12-7.01(\mathrm{~m}, 3 \mathrm{H}), 6.99-6.90(\mathrm{~m}, 1 \mathrm{H}), 6.26-6.18(\mathrm{~m}, 2 \mathrm{H}), 6.06$ $(\mathrm{d}, J=5.6 \mathrm{~Hz}, 1 \mathrm{H}), 5.68-5.55(\mathrm{~m}, 1 \mathrm{H}), 4.57-4.45(\mathrm{~m}, 1 \mathrm{H}), 4.44-4.30(\mathrm{~m}, 1 \mathrm{H}), 2.28-2.14(\mathrm{~m}, 2 \mathrm{H})$, $2.11(\mathrm{~s}, 3 \mathrm{H}), 2.04-1.86(\mathrm{~m}, 2 \mathrm{H}), 1.73-1.45(\mathrm{~m}, 2 \mathrm{H})$. 


\section{Assay conditions}

BTK Binding Assay. Recombinant, unphosphorylated-BTK (UP-BTK) kinase domain was purchased from Proteros GmbH (Munich, Germany). Eu-anti-GST antibody, kinase buffer, and Alexa-Fluor 647-labeled kinase tracer were purchased from Invitrogen (Carlsbad, CA).

To determine the binding affinity for each compound, a BTK kinase Lanthascreen assay was utilized to monitor compound binding to UP-BTK by competing with a fluorescent-labeled tracer. Titrations of compound in DMSO were added to 384-well plates, followed in succession by 2.67 nM UP-BTK, $2.0 \mathrm{nM}$ detection antibody, and $50 \mathrm{nM}$ tracer in kinase buffer. The plates were incubated for $1 \mathrm{hr}$ at room temperature and fluorescence read on Infinite F500 from Tecan.

Emission ratio (ER) was calculated by dividing the reading at $665 \mathrm{~nm}$ by the reading at $615 \mathrm{~nm}$. Inhibition rate $(\mathrm{IR} \%)$ was determined by the following equation: $I R \%=\left(\mathrm{ER}_{\mathrm{high}}-\mathrm{ER}_{\text {compound }}\right) \mathrm{x}$ $100 /\left(\mathrm{ER}_{\text {high }}-\mathrm{ER}_{\text {low }}\right)$, where $\mathrm{ER}_{\text {high }}, \mathrm{ER}_{\text {low }}$, and $\mathrm{ER}_{\text {compound }}$ refer to the emission ratio of the high control (no compound), low control (no enzyme), and compound treated wells, respectively. The $\mathrm{IC}_{50}$ for each compound was then calculated from the $\mathrm{IR} \%$ of the titrations using a four-parameter logistic regression (4-PL) fit.

Determination of inhibitor potency $\left(k_{\text {inact }} / K_{I}\right.$ ratios). Full-length BTK enzyme was purchased from Carnabio USA (Natick, MA). Srctide (NH2-KKKAPFSWYLPEEG) was purchased from Anaspec (Fremont, CA). ATP, phosphoenolpyruvate, nicotinamide adensine dinucleotide reduced form (NADH), pyruvate kinase/lactic dehydrogenase (PK/LDH), $\mathrm{MgCl}_{2}$, tris(2-carboxyethyl)phosphine (TCEP) and pluronic F127 were purchased from Sigma. 1 M Hepes-NaOH (pH 7.5) and Tween20 were purchased from Teknova and Enzo, respctively. Transparent 384-well plates were purchased from Greiner. To determine $k_{\text {inact }} / K_{\mathrm{I}}$ ratio for each compound, BTK reaction progress at each compound concentration was monitored by using PK/LDH assay, which couples adenosine 
diphosphate (ADP) production from kinase activities to oxidation of NADH. ${ }^{28}$ Assays were performed in transparent 384-well plates in the assay mixture containing $50 \mathrm{mM}$ Hepes- $\mathrm{NaOH}$ (pH 7.5), $10 \mathrm{mM} \mathrm{MgCl} 2,0.24 \mathrm{mM}$ ATP, $0.45 \mathrm{mM}$ srctide (NH2-KKKAPFSWYLPEEG), 0.50 $\mathrm{mM}$ phosphoenolpyruvate, $0.30 \mathrm{mM} \mathrm{NADH}, 12-20 \mathrm{U} / \mathrm{mL}$ pyruvate kinase, $18-28 \mathrm{U} / \mathrm{mL}$ lactic dehydrogenase, $0.002 \%$ Tween-20, $1 \mathrm{mM}$ TCEP, and $0.01 \%$ Pluronic F127, and the indicated concentrations of inhibitor (or DMSO). Reactions were initiated by the addition of $1 \mathrm{nM}$ fulllength BTK enzyme and the final concentration of DMSO was kept at $0.1 \%$. The substrate concentrations for the assay were at the $K_{\mathrm{M}}$ value and 3-times of the $K_{\mathrm{M}}$ value for ATP and the peptide substrates, respectively. Background reactions without the BTK enzyme were subtracted from all reactions with the enzyme. Reaction time courses were monitored at RT by recording absorbance at $340 \mathrm{~nm}$ for 2 hours with readings taken 2-min intervals on Tecan Spark microplate reader (Tecan U. S., Morrisville, NC) equipped with SparkControl software. The reaction progress curves corresponding to the linear range of the DMSO control for 2 hours were fit to eq 1:

$$
\text { Product }=\frac{V_{0}}{k_{\mathrm{obs}}} \quad\left[1-\exp \left(-k_{\mathrm{obs}} t\right)\right]
$$

where $V_{\mathrm{o}}$ is the initial rate and $t$ is time, to obtain the first order rate constant for enzyme inactivation $\left(k_{\mathrm{obs}}\right)$ at each inhibitor concentration. The $k_{\mathrm{obs}}$ values were then plotted versus inhibitor concentration ([I]) and fit to eq 2:

$$
k_{\mathrm{obs}}=\frac{k_{\text {inact }}[\mathrm{I}]}{K_{\mathrm{I}}+[\mathrm{I}]}
$$

where $k_{\text {inact }}$ is the maximal rate of inactivation and $K_{\mathrm{I}}$ is the inhibitor concentration that yields half the rate of maximal inactivation. The $k_{\text {inact }}$ and $K_{\mathrm{I}}$ values determined were used to calculate the overall potency 
$k_{\text {inact }} / K_{\mathrm{I}}$ ratios. ${ }^{23}$ For highly potent compounds with $K_{\mathrm{I}}$ values close to or less than the enzyme concentration $(1 \mathrm{nM})$, assays were performed again at higher ATP concentration $(4.8 \mathrm{mM}$, which is 20 -fold of the $K_{\mathrm{M}}$ value) to ensure more accurate determination of potency. $K_{\mathrm{I}}$ at $0.24 \mathrm{mM}$ ATP was then calculated by dividing the apparent $K_{\mathrm{I}}$ at $4.8 \mathrm{mM}$ ATP by 10.5 .

Determination of rotational interconversion barriers $\Delta G^{t}$ rot ${ }^{29}$ Resolved atropisomers were heated in aqueous ethanol and the appearance of the alternate atropisomers were quantified by chiral SFC with UV detection at $254.4 \mathrm{~nm}$. The rate constants for racemization were determined from the relative quantities of the two atropisomers as a function of time according to equation 3.

$k=\frac{1}{2} \frac{d \ln \left(\frac{1+D: L}{1-D: L}\right)}{d t}$.

The rotational energy barriers $\Delta \mathrm{G}_{\text {rot }}^{\ddagger}$ were calculated from the rate constants for racemization according to equation 4 .

$\mathrm{k}=\mathrm{Ae}-\Delta \mathrm{G} \sharp \mathrm{rot} / \mathrm{RT}$

Covalent adduct assay. In this assay, recombinant purified BTK kinase domain (Proteros) is reacted to completion with the inhibitor. Aliquots of the reaction are then run over a C18 reversed phase HPLC column (Phenomenex Aeris Widepore, 50 x $2.1 \mathrm{~mm}, 3.6 \mathrm{um}$ ) under non-denaturing (native) conditions and under denaturing conditions (8M urea, $70^{\circ} \mathrm{C}$ ) using an Agilent 1290 uHPLC system with dual column setup. The HPLC is coupled to an Agilent 6550 qTOF mass spectrometer to enable precise identification of free protein and adduct by mass. The area under 
the peak of the resulting chromatogram is proportional to the amount of detected protein and is used to calculate the percentage of free and modified BTK.

Mouse CD69 Primary Cell Assay. Anti-mouse IgM was purchased from Jackson ImmunoResearch (West Grove, PA). Mouse CD19-APC and mouse CD69-FITC antibodies were purchased from BD Pharmingen (San Diego, CA).

To determine the potency of each compound, inhibition of anti-IgM-induced B cell activation in mouse primary cells was assessed by flow cytometry. Mouse splenocytes were prepared from C57B1/6 mice into complete culture media (RPMI 1640, 10\% fetal bovine serum, 2 mM Glutamax (Gibco) ) and seeded at a density of $2 \times 10^{6}$ cells $/ \mathrm{mL}$, followed by a 1 hour incubation with a titration of compound in DMSO and overnight incubation with anti-IgM ( $5 \mu \mathrm{g} / \mathrm{mL}$ in media). Cells were then collected by centrifugation and stained with fluorescent antibodies against CD19 and CD69 for 30 minutes, washed, fixed (1\% paraformaldehyde), and acquired on FACSCalibur or FACSCanto II (BD Biosciences).

Each sample was gated on forward and side scatter for lymphocytes and on CD19+ for B cells. The percentage of activated B cells was defined as the proportion of CD19+CD69+ cells over total CD19+ cells.

Rat Whole Blood Assay. Anti-rat IgD was purchased from AbD Serotec (Oxford, United Kingdom). Rat B220-PE and rat CD86-FITC were purchased from eBioscience (San Diego, CA). Lysing buffer was purchased from BD Biosciences (San Diego, CA).

To determine the potency of each compound, inhibition of anti-IgD-induced activation of B cells in rat whole blood was assessed by flow cytometry. Heparinized blood was collected from Wistar rats, supplemented with penicillin $(100 \mathrm{U} / \mathrm{mL})$ and streptomycin $(100 \mu \mathrm{g} / \mathrm{mL})$, and incubated for 
1 hour with a titration of compound in DMSO ( $0.3 \%$ final concentration). The blood was then stimulated and incubated overnight at $37{ }^{\circ} \mathrm{C}$ with anti-IgD $(10 \mu \mathrm{g} / \mathrm{mL})$. The samples were then stained with fluorescent antibodies against CD86 and B220 for 30 minutes, red blood cells removed with lysing buffer, washed, fixed, and acquired on FACSCalibur.

Each sample was gated on forward and side scatter for lymphocytes and on B220+ for B cells. The percentage of activated B cells was defined as the proportion of B220+CD86+ cells over total B220+ cells.

Inhibition percentage was determined by the following equation: Inhibition $\%=\left(\mathrm{ActB}_{\text {stim }}-\right.$ $\left.\mathrm{ActB}_{\text {compound }}\right) \times 100 /\left(\mathrm{ActB}_{\text {stim }}-\mathrm{ActB}_{\text {unstim }}\right)$, where $\mathrm{ActB}_{\text {high }}, \mathrm{ActB}_{\text {unstim }}$, and $\mathrm{ActB}_{\text {compound }}$ refer to the percentage of activated B cells of the stimulated (no compound), unstimulated (no antibody), and compound treated wells, respectively. The $\mathrm{IC}_{50}$ for each compound was then calculated from the inhibition $\%$ of the titrations using a 4-PL fit.

Human whole blood assay. $160 \mu \mathrm{L}$ of human whole blood was incubated with $20 \mu \mathrm{L}$ of titrated compounds for 30-60 minutes and stimulated for 18 hours with $20 \mu \mathrm{L}$ of anti-IgM (30 $\mu \mathrm{g} / \mathrm{mL}$, Jackson ImmunoResearch) at $37^{\circ} \mathrm{C}$. Test compounds were tested in duplicate during each $\mathrm{IC}_{50}$ determination. The next day, the cells were stained for 1 hour with fluorescent antibodies to CD19 and CD69 (R\&D). The red blood cells were lysed (buffer EL, Qiagen) and the samples read using a FACSC anto II (BD). Graphpad Prism 5, version 5.01, was used to generate a concentration response curve and $\mathrm{IC}_{50}$ values.

Inhibition percentage was determined by the following equation: Inhibition $\%=\left(\mathrm{ActB}_{\mathrm{stim}}-\right.$ $\left.\mathrm{ActB}_{\text {compound }}\right) \times 100 /\left(\mathrm{ActB}_{\text {stim }}-\mathrm{ActB}_{\text {unstim }}\right)$, where $\mathrm{ActB} \mathrm{B}_{\text {high }}, \mathrm{ActB}_{\text {unstim, }}$, and $\mathrm{ActB}_{\text {compound }}$ refer to the percentage of activated B cells of the stimulated (no compound), unstimulated (no antibody), 
and compound treated wells, respectively. The $\mathrm{IC}_{50}$ for each compound was then calculated from the inhibition \% of the titrations using a 4-PL fit.

Liver Microsomal Metabolic Stability Assay. The liver microsomal metabolic stability assay was conducted at Cyprotex. The microsomes used for metabolic stability studies were as follows: human liver microsomes (pooled male and female), rat liver microsomes (pooled male Sprague Dawley rats), mouse liver microsomes (pooled male CD mice), dog liver microsomes (male beagle), and monkey liver microsomes (male cynomolgus). Microsomes (final protein concentration $0.5 \mathrm{mg} / \mathrm{mL}$ ), $0.1 \mathrm{M}$ phosphate buffer $\mathrm{pH} 7.4$ containing $1 \mathrm{mM} \mathrm{MgCl} 2$ and test compound (final substrate concentration $1 \mu \mathrm{M}$; final DMSO concentration $0.05 \%$ ) were preincubated at $37{ }^{\circ} \mathrm{C}$ prior to the addition of NADPH (final concentration $1 \mathrm{mM}$ ) to initiate the reaction. At 6 time points $(0,5,10,20,40$ and $60 \mathrm{~min})$ reactions were stopped by the removal of $50 \mu \mathrm{L}$ of the incubation mixture into methanol. The incubation plates were centrifuged at 2,500 rpm for 20 min at $4{ }^{\circ} \mathrm{C}$ to precipitate the protein. Following protein precipitation, the sample supernatants were combined in cassettes of up to 8 compounds and analyzed using LC-MS/MS conditions.

The compound half-lives were derived from plots of the ln of percent remaining compound over time to determine the intrinsic clearance. The predicted hepatic clearance was derived from the intrinsic clearance value using equations from the well-stirred model, where no correction was made for plasma protein or liver microsomal binding and the blood to plasma concentration ratio was assumed to be one. The extraction ratio (ER) was calculated by dividing the predicted hepatic clearance by species blood flow (Q), where $\mathrm{Q}$ is $150,70,31,44$, and $21 \mathrm{~mL} / \mathrm{min} / \mathrm{kg}$ for mouse, rat, dog, monkey and human, respectively. 
Pharmacokinetic Studies. Compound 27 was formulated in $20 \% \mathrm{HP}-\beta-\mathrm{CD}$ to prepare a $1 \mathrm{mg} / \mathrm{mL}$ solution.

Rat pharmacokinetic studies were conducted by Biodura, Shanghai. Separate cohorts $(n=3)$ of non-fasted male Sprague Dawley rats were administered compound 27 at a dose of $1 \mathrm{mg} / \mathrm{kg} \mathrm{IV} \mathrm{or}$ $5 \mathrm{mg} / \mathrm{kg}$ PO as a solution. Blood samples were collected at 0.033 (IV only), 0.083 (IV only), 0.25 , $0.5,1,2,4,8$, and $24 \mathrm{~h}$ post dose after administration via the jugular vein catheter. Blood samples were collected into tubes containing $\mathrm{K}_{2}$ EDTA and placed on wet ice. The plasma fraction was separated by centrifugation and kept frozen at $-20{ }^{\circ} \mathrm{C}$. Concentrations of compound 27 in plasma were determined using a qualified liquid chromatography-triple quadrupole mass spectrometry (LC-MS/MS) method with a limit of quantification (LOQ) of $1 \mathrm{ng} / \mathrm{mL}$.

Dog pharmacokinetic studies were conducted internally at Janssen Research \& Development. Six male beagle dogs were fasted overnight prior to dosing and food was withheld through the first 4 hours of blood sample collection. Compound 27 was administered to the IV cohort $(n=3)$ via a single IV bolus dose of $0.5 \mathrm{mg} / \mathrm{kg}$ and to the PO cohort $(\mathrm{n}=3)$ orally via stomach intubation with a dose of $2.5 \mathrm{mg} / \mathrm{kg}$. Blood samples were collected at pre-dose, 0.033 (IV only), 0.083 (IV only), $0.25,0.5,1,2,4,7$, and $24 \mathrm{~h}$ post dose. Blood samples $(\sim 1 \mathrm{~mL})$ were obtained from the jugular or cephalic veins, collected into tubes containing $\mathrm{K}_{2}$ EDTA, and placed on wet ice. The samples were centrifuged and the resulting plasma was separated and stored frozen at $-70{ }^{\circ} \mathrm{C}$. Concentrations of compound $\mathbf{2 7}$ in plasma were determined using a qualified liquid chromatography-triple quadrupole mass spectrometry (LC-MS/MS) assay with a LOQ of $1 \mathrm{ng} / \mathrm{mL}$.

Pharmacokinetic parameter values were derived from noncompartmental analysis of the plasma concentration versus time data using Phoenix WinNonlin software (Certara, Princeton, NJ). Half-life was not reported if $<3$ data points were used to define the terminal phase. 
In vivo BTK occupancy. Compound 27 or vehicle (20\% HP $\beta C D)$ was administered orally to female Wistar rats (approximately 154-170 g at time of study), and blood was obtained into heparinized tubes by retroorbital bleeding at $2,4,8,24,32$, and 48 hours after dosing. Half of each sample was prepared into plasma by centrifugation $\left(5000 \mathrm{rpm}\right.$ for $10 \mathrm{~min}$ in $\left.4{ }^{\circ} \mathrm{C}\right)$ and compound levels measured by LC/MS. The other half was used to assess BTK protein occupancy by ELISA. Cell lysates were prepared from the blood, and free BTK protein was tagged by a biotinylated probe which was then captured on the surface of a streptavidin-coated microtiter plate and detected by ELISA using an antibody specific for BTK (BD Transduction). Percent free BTK was calculated by dividing the background adjusted optical densities of samples from rats administered compound 27 by samples from rats administered vehicle. Percent BTK occupancy was defined as $100 \%$ minus percent free BTK.

Collagen induced arthritis model. Female Wistar rats (Shanghai SLAC Laboratory Animal Co Ltd) were approximately $133-163 \mathrm{~g}$ (6-8 weeks of age) at initiation of dosing. Hydroxypropyl- $\beta$ cyclodextrin $(\mathrm{HP} \beta \mathrm{CD} ; 20 \% \mathrm{w} / \mathrm{v})$ solution was prepared in distilled water, adjusted $\mathrm{pH}$ to 2.1 with $6 \mathrm{M} \mathrm{HCl}$ and used as the vehicle. YiSaiPu, a recombinant human Tumor Necrosis Factor- $\alpha$ Receptor II: IgG Fc fusion protein was used as a control (Lot: 201405038/201407028) (Shanghai CP Guojian Pharmaceutical Co., Ltd., Shanghai, P.R.China). Collagen from bovine cartilage, Type II (CII) (Chondrex; Redmond, WA, USA) and Incomplete Freund's adjuvant (IFA) (SigmaAldrich, St. Louis, MO, USA) was used to initiate disease. Type II collagen was dissolved at a concentration of $2 \mathrm{mg} / \mathrm{mL}$ in $100 \mathrm{mM}$ acetic acid by stirring at $4{ }^{\circ} \mathrm{C}$ overnight. A high-speed homogenizer $(28,000 \mathrm{rpm}$, FLUKO Equipment Shanghai Co., Ltd) was used to emulsify the 2 $\mathrm{mg} / \mathrm{mL} \mathrm{CII} \mathrm{solution} \mathrm{in} \mathrm{an} \mathrm{equal} \mathrm{volume} \mathrm{of} \mathrm{the} \mathrm{IFA} \mathrm{on} \mathrm{ice} \mathrm{for} 3 \mathrm{~min}$. 
Arthritis was induced by intradermal injection of CII in IFA. ${ }^{30} 104$ rats were used in the study. Before immunization, 6 rats were randomly selected as a naïve group. The other 98 rats were anesthetized with inhalational isoflurane and injected intradermally at the base of the tail with 0.2 $\mathrm{mL}$ of the emulsion ( $1 \mathrm{mg} / \mathrm{mL} \mathrm{CII/IFA),} 2-3 \mathrm{~cm}$ from the body on day 0 and day 7 . On day 9 , out of the 98 rats that were immunized, the 48 rats with the most developed arthritis based on paw volume measurements were divided into 6 groups $(n=8)$ with a stratified random block design according to average hind paw volume of each rat. Vehicle or different doses of compound $\mathbf{2 4}$ were administered QD (once a day) from day 9 to day 16; anti-TNF was administered QOD (once every other day) on days $9,11,13$, and 15 . Left and right hind paw volumes were measured by a Plethysmometer (Catalog No. 7140, Ugo Basile. Italy) and body weight was monitored daily for 7 consecutive days after initiation of test article dosing.

T Cell IL-2 Assay. An IL-2 ELISA assay was developed to assess the activity of BTK inhibitors in human $\mathrm{T}$ cells. The assay uses anti-CD3 and anti-CD28 antibodies to trigger general $\mathrm{T}$ cell activation. A cytokine, IL-2, produced during T cell activation was measured using an ELISA assay.

Briefly, $90 \mu \mathrm{L}$ of human CD4+ T cells were incubated with $10 \mu \mathrm{L}$ of titrated compounds for $30-$ 60 minutes and stimulated for 18 hours with $10 \mu \mathrm{L}$ of anti-CD3 $(1 \mu \mathrm{g} / \mathrm{mL}, \mathrm{BD})$ and anti-CD28 $\left(1 \mu \mathrm{g} / \mathrm{mL}\right.$, eBioscience) at $37^{\circ} \mathrm{C}$. JNJ-64264681 was tested in duplicate during each $\mathrm{IC}_{50}$ determination. The next day, the supernatant was collected and the concentration of IL-2 was determined with an ELISA assay. An ITK inhibitor was included as a positive control in all experiments. 


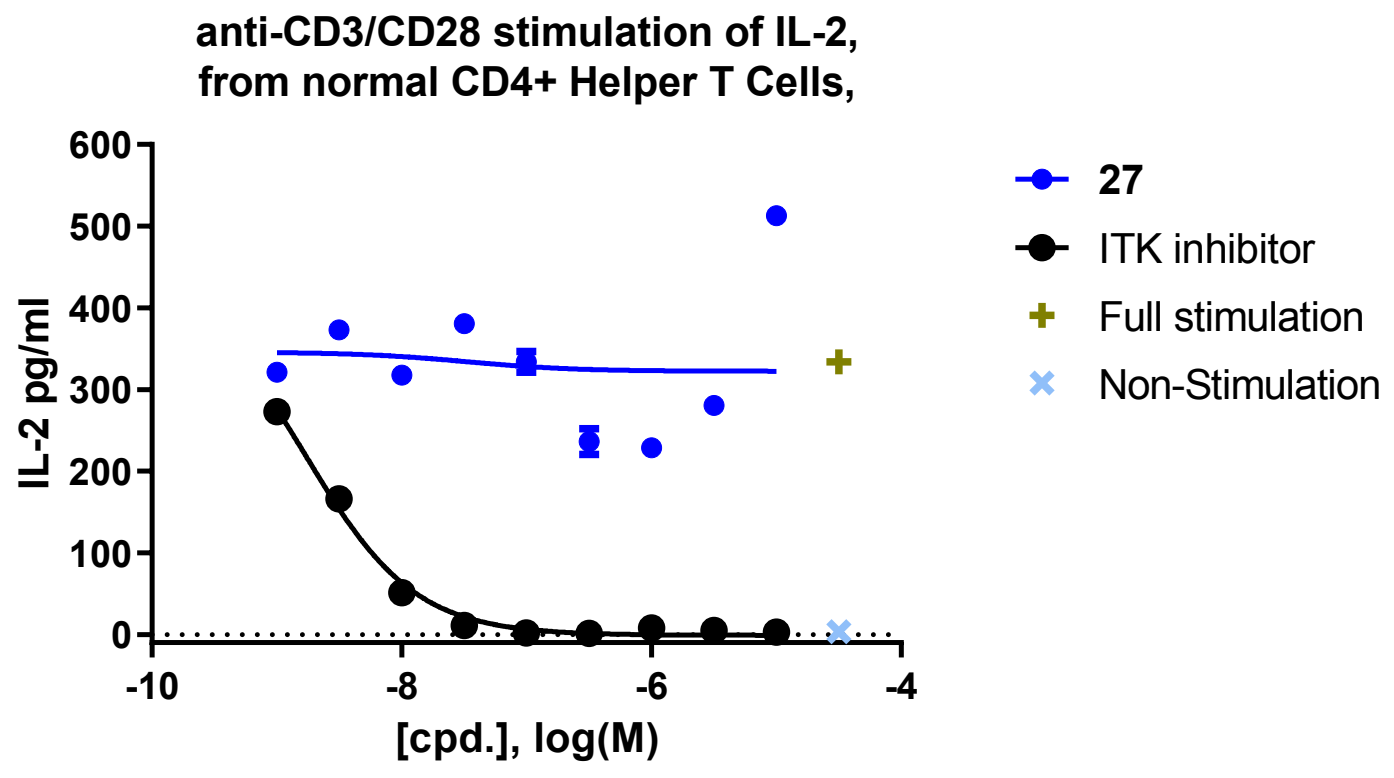

